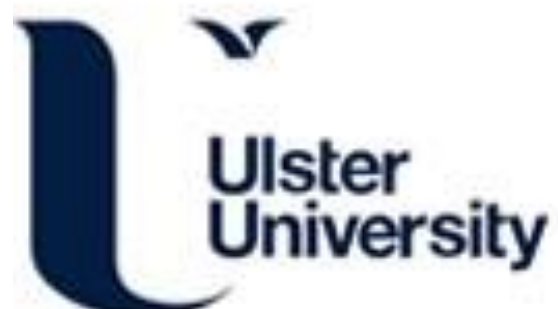

\section{Engineering egress data considering pedestrians with reduced mobility}

Geoerg, P., Berchtold, F., Gwynne, S., Boyce, K. E., Holl, S., \& Hofman, A. (2019). Engineering egress data considering pedestrians with reduced mobility. Fire and Materials, 43(7), 759-781.

https://doi.org/10.1002/fam.2736

Link to publication record in Ulster University Research Portal

\section{Published in:}

Fire and Materials

Publication Status:

Published (in print/issue): 16/10/2019

DOI:

10.1002/fam. 2736

\section{Document Version}

Author Accepted version

\section{General rights}

Copyright for the publications made accessible via Ulster University's Research Portal is retained by the author(s) and / or other copyright owners and it is a condition of accessing these publications that users recognise and abide by the legal requirements associated with these rights.

\section{Take down policy}

The Research Portal is Ulster University's institutional repository that provides access to Ulster's research outputs. Every effort has been made to ensure that content in the Research Portal does not infringe any person's rights, or applicable UK laws. If you discover content in the Research Portal that you believe breaches copyright or violates any law, please contact pure-support@ulster.ac.uk. 


\title{
Engineering egress data considering pedestrians with reduced mobility
}

\author{
Paul Geoerg, ${ }^{\mathrm{a}, 1}$, Florian Berchtold ${ }^{\mathrm{a}}$, Steven Gwynne ${ }^{\mathrm{b}}$, Karen Boyce ${ }^{\mathrm{c}}$, Stefan Holl ${ }^{\mathrm{d}}$, Anja Hofmann ${ }^{\mathrm{a}}$ \\ ${ }^{a}$ Bundesanstalt für Materialforschung und -prüfung (BAM), Berlin, Germany \\ (Paul.Geoerg;Florian.Berchtold;Anja.Hofmann)@bam.de \\ ${ }^{b}$ Movement Strategies, London, United Kingdom,smvgnrc@gmail.com \\ ${ }^{c}$ Ulster University, Coleraine, United Kingdom,KE.Boyce@ulster.ac.uk \\ ${ }^{d}$ Forschungszentrum Jülich GmbH, Jülich, Germany, St.Holl@fz-juelich.de
}

To quantify the evacuation process, evacuation practitioners use engineering egress data describing the occupant movement characteristics. This data are typically based to young and fit populations. However, the movement abilities of occupants who might be involved in evacuations are becoming more variable - with the building populations of today typically including increasing numbers of individuals: with impairments or who are otherwise elderly or generally less mobile. Thus, there will be an increasing proportion of building occupants with reduced ability to egress. For safe evacuation, there is therefore a need to provide valid engineering-egress data considering pedestrians with disabilities.

Gwynne and Boyce recently compiled a series of data-sets related to the evacuation process to support practitioner activities in the chapter Engineering Data in the SFPE handbook of fire protection engineering. This paper supplements these data-sets by providing information on and presenting data obtained from additional research related to the pre-movement and horizontal movement of participants with physical, cognitive- or age-related disabilities. The aim is to provide an overview of currently available data-sets related to, and key factors affecting the egress performance of, mixed ability populations which could be used to guide fire safety engineering decisions in the context of building design.

Keywords: egress, disability, movement, pre-movement, evacuation, mobility, pedestrians, engineering data

E-Mail: paul.geoerg@bam.de (Paul Geoerg) 


\section{Introduction}

Evacuation practitioners need to identify and employ data to characterise occupants and their occupancy for the evaluation of the overall evacuation time of buildings. Establishing the overall evacuation time for a number of fire scenarios is a key component in performance-based design. This time is typically compared to the time where the environmental conditions become untenable [1], [2]. Performance-based design represents one of the two key regulatory approaches to life safety, where the other is a prescriptive approach. As part of performance-based design, engineering data relating to evacuee movement are necessary to establish building safety in response to representative emergency scenarios [3]. Practitioners employ calculations and simulation tools to quantify evacuation performance using such data ([4], [5]). In addition, this data is key both in the development of engineering calculations and simulation tools and in the testing of such tools $([6],[7])$. This is a challenging task that is made more difficult as data are typically scarce, partial and often detached from context. This context is required for the practitioner to make an informed assessment and, without it, data might be employed that are inappropriate to the scenario being examined.

Many of the data-sets used today (like [8], [9], [10], [11] and [12]) were developed or collected some decades ago. It is debatable whether these data-sets are still representative given the limited data collection techniques employed at the time, a less mature understanding of the evacuation process and also changing scenario conditions (e.g. changes in the population dynamics, building designs, procedural measures, etc.)[13]. For instance, examining populations ages in Canada, UK, Japan, US, France and Germany we see the median has moved from 35-40 years in 2000 to 40-45 years in 2017 [14]. This change is also reflected in the 'population barrels' (formerly known as 'population pyramids') for Germany, Canada and the UK where an obvious ageing of the population is apparent when comparing statistics for 1995 and 2015 (see Fig 2). As well as being an ageing society, obesity increases in developing countries [15] where obese individuals are subjected to a higher risk of having a mobility disability [16]. Furthermore, the prevalence of single- or severely disabled increases with age, especially in an age older than 50 years (Fig 1 ).

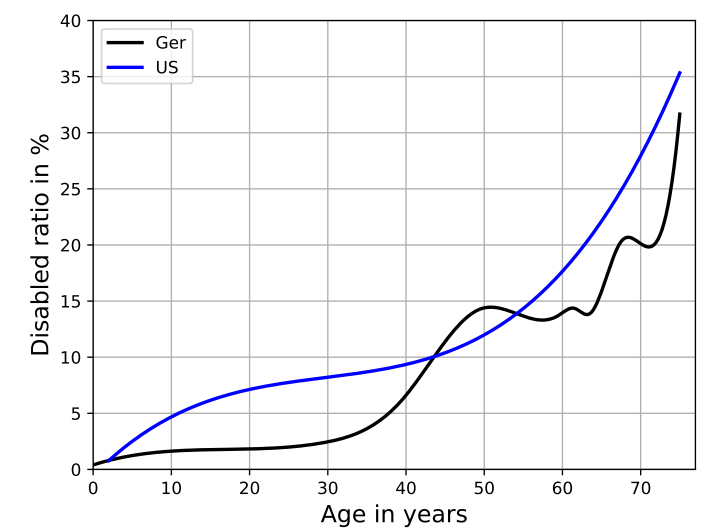

(a) Ratio of severely disabled persons in Germany and the United States.

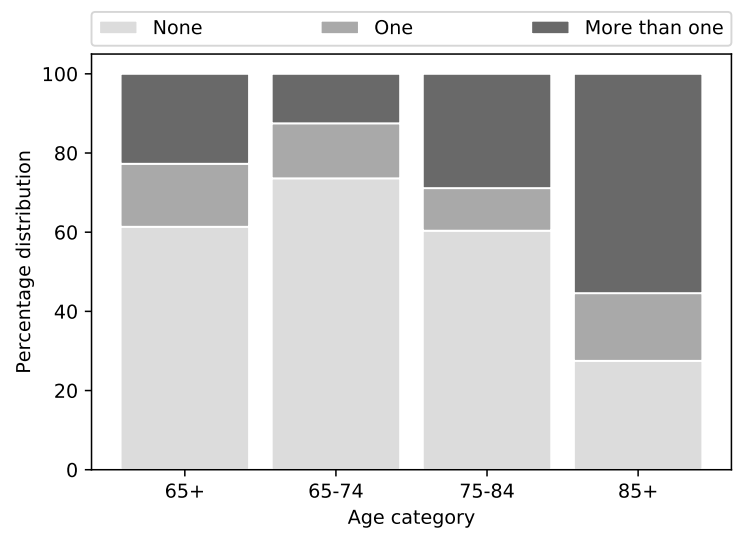

(b) Population aged $65+$ by number of disabilities in the United States.

Figure 1: Percentage with disabilty across the life span. Ratio of severely disabled persons in Germany 17 and the United States (2013) [18] (left). Population aged 65+ by number of disabilities depending on age (2008-2012) [19] (right).

These demographic changes have complex impacts on society and on the evacuation process. Such impacts might include increased number of elderly people living in mixed occupancy buildings affecting the relevance of emergency procedures [20], increased social pressures on neighbours and fellow evacuees to provide assistance during an incident, increased proportion of the population with a movement disability that affects evacuation performance (both of those with the disabilities and those around them) and an increased requirement for responders to rescue residents. 
Gwynne and Boyce [21] recently compiled a series of data-sets related to the process of evacuation to support practitioner activities in their SFPE handbook chapter entitled Engineering Data. This included data collected between 1985 - 2012 which were presented in a standardized manner in conjunction with core background information. Although comprehensive, such actions are always limited by the time at which they are conducted and therefore necessarily excludes research since that time. Whilst it is acknowledged that some data-sets described by Gwynne and Boyce focused on people with disabilities and that they presented some data on assisted movement, most data sets neither involved people with disabilities or reduced performance, e.g. children, or they did not adequately document the disability-status. Most data sets focussed on those without reduced mobility or did not adequately document the particular limitations of those involved. Data regarding people with disabilities was categorised by assisted and unassisted unimpeded (free) movement speeds on the horizontal, ramps, ascending or descending stairs and door traversals.

To summarise, social-demographics in western societies are changing as the way of living and the kind of dwellings. Particularly in the context of these developments and associated lack of data, it is pertinent to extend the understanding of movement behaviour of heterogeneous pedestrian groups. This paper gives a brief review of the established structure of the evacuation process (Sec 2). After an extended review of literature (Sec 3), a comprehensive update of data-sets considering pedestrians with physical, mental- or aged-related disabilities and reduced performance (Sec 4.1, Sec 4.2 and Sec,4.3) are presented. This analysis enables the identification of key factors influencing sensitive subprocesses of an evacuation for building designers, fire safety- and safety engineers.

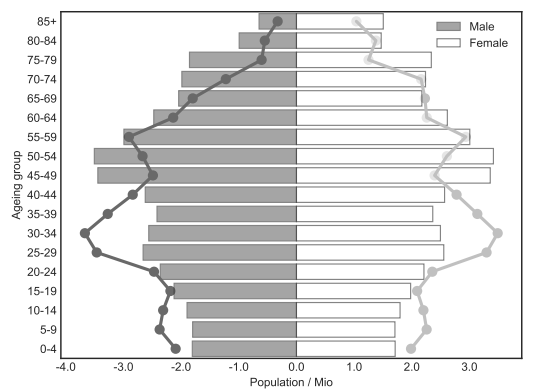

(a) Germany.

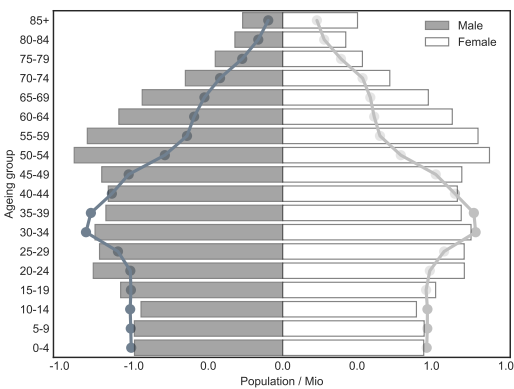

(b) Canada.

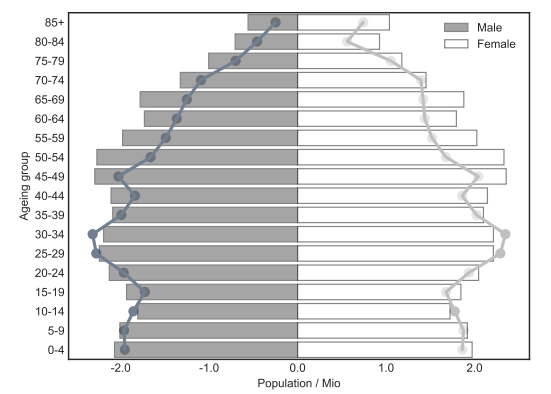

(c) United Kingdom.

Figure 2: Ageing pyramid depending on gender for the population of Germany, Canada and the United Kingdom. Current demographic trends mean that societies in developed countries are growing older. The ratio between inhabitants older than 65 years and between the age of 15 and 65 (ageing quotient) is increasing as well.

Data of the census 2015 is plotted by bars, line plots representing the data of the census 1995 .

Source: [22].

\section{Background}

\subsection{Evacuation process}

Evacuee response to an incident is a combination of individual attributes, decisions and actions, social factors, procedural factors, spatial factors, and environmental conditions [23] which interact in many ways and influence the evacuation. It is arguably not practical for engineering models (calculations or simulations) to address all these elements. Calculation methods require a reduction of reality, thus making assumptions in the development of a model. This applies to all types of models, e.g. an evacuation training tool or calculation software for pedestrian movement which has implemented a model comprising agents, their interactions, responses, movement etc. A well established model of the evacuation process is called the 'engineering timeline' [1], [2], [24], which is also implemented by BS PD 7974-6 [25] and ISO TS 29761:2015 [26]. The engineering time line compares the RSET (Required Safe Escape Time) i.e. the time required from ignition of a fire until all occupants can reach an area of safety with the ASET (Available Safe Egress Time), 
i.e. the time available between ignition of a fire and the time at which tenability criteria are exceeded in the means of egress. The aim of this comparison is to ensure that the ASET should be longer than the RSET by an acceptable margin of safety. The RSET is separated into two main parts: the pre-movement and the movement phase. The pre-movement time relates to the interval between the time at which a general alarm signal or warning is given and the time at which the first deliberate evacuation movement is made. The movement time is the time needed, once movement toward an exit has begun, for all occupants to reach a place of safety. The influence of each part on the main results, namely the predicted required safe egress time, also called evacuation time. This time depends on the scenario, e.g. usage and spatial surroundings of the building, characteristics of evacuees and technological boundaries.

As a baseline, evacuation assessment addresses the physical movement involved in the evacuation process. The assessment typically employs factors like expected travel speeds, flow, and densities [27]. These factors are related through, so called, fundamental diagrams which allow achievable travel rates (speeds and flow) to be established based on route capacity and population size (e.g. [28], [29], [30], [31], [32], [33]). The physical movement is initiated after a delay period (pre-movement time $e^{1}$ based on the evacuee reception, perception and interpretation of the conditions faced, e.g. fire conditions, actions of others, alarm type, proximity to incident, etc. This is typically characterized by a delay time that captures the numerous factors. Data is therefore required to represent these delays and travel rates.

Engineering and computational models are generally employed to quantify an engineering time line for representative scenarios or some aspect of it. This time line typically represents an aggregate level of performance - at the level of the population - rather than the individual i.e. where a representative value or distribution for the initial delay and movement rates are employed to represent population performance. This simplification is necessary to generalize the time line across fire incidents. This time line can be characterised by several phases: the detection and warning phase, the pre-movement phase and the movement phase (e.g. [2]). The first phase is automated in many situations, i.e. is reliant on the activation time of technology and so is often represented by manufacturer information on device performance rather than human response data. In other situations, i.e. in the absence of automatic detection and alarm, reliance is on manual detection and activation which can be 'long and unpredictable' [25]. The pre-movement phase represents the time between the population becoming aware of the incident (e.g. through the raising of the alarm) and the time at which they initiate movement towards a place of safety. The travel phase represents the time between initiating movement to a place of safety and arrival at a place of safety (consisting of movement, queuing and non-evacuation activities).

\subsection{Original work}

Gwynne and Boyce [21] presented engineering data sets according to the key behavioural components that comprise the engineering time line in the chapter Engineering Data of the SFPE handbook of fire protection engineering [35] in a tabular format (Fig 3). The tables further describe the background and the key results of the data. Further information in the chapter of Gwynne and Boyce facilitates the interpretation and understanding of the context of the results and helps to differentiate between them.

The tables address data following the engineering timeline: detection, pre-movement time (with data distinguishing between occupant status/disability, i.e. awake or asleep, and by occupancy type), and travel time (horizontal and stair speed/flow, exit flow, escalator traversal, ramp traversal, and movement through smoke). For each key behavioural component, the tables provide information on the original scenario (called Observational Conditions). This comprised the original country or city in which the study or event of data collection took place, its nature, (whether an unannounced evacuation, an announced evacuation, laboratory experiment, etc.), the spatial environment, the environmental conditions, the participants and the variables examined. For further details on the structure of data presentation we refer to the original

\footnotetext{
${ }^{1}$ The terms 'pre-movement time' and 'pre-evacuation time' are used interchangeably in the literature. Pre-movement, although not considered the most appropriate term as it may include movement, is used here because it is the term commonly used in regulations and guidance, e.g. in [4], [34].
} 
work [21. Furthermore, information on the sample size and make-up, the data collection approaches, and the results (mean, standard deviation, range are given). The tables had to be slightly customized to account for differences in the engineering data (Fig 30 .

\begin{tabular}{|c|c|c|c|c|c|c|c|c|c|}
\hline \multirow[b]{2}{*}{ 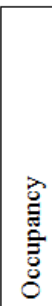 } & \multirow{2}{*}{$\begin{array}{l}\text { Source } \\
\text { Author } \\
\text { Year }\end{array}$} & \multirow[b]{2}{*}{$\begin{array}{l}\text { Observational } \\
\text { Conditions } \\
\text { (L: Location, } \\
\text { N:Nature, SC: } \\
\text { Spatial Configu- } \\
\text { ration, } \\
\text { P:Participants, } \\
\text { E:Environment, } \\
\text { V:Variable) }\end{array}$} & \multicolumn{3}{|c|}{ Procedure } & \multicolumn{2}{|c|}{ Sample } & Results (sec) & \multirow{2}{*}{$\begin{array}{l}\text { Additional } \\
\text { Information }\end{array}$} \\
\hline & & & Strategy & Staff & Technology & $\begin{array}{l}\text { Collection } \\
\text { Method }\end{array}$ & Size & $\begin{array}{c}\text { Mean } \\
{[\text { S.D, Range] }}\end{array}$ & \\
\hline
\end{tabular}

(a) Pre-movement time / s table heading.

\begin{tabular}{|c|c|c|c|c|c|c|c|}
\hline \multirow{2}{*}{$\begin{array}{l}\text { Source } \\
\text { (author, year) }\end{array}$} & \multirow{2}{*}{$\begin{array}{l}\text { Observational Conditions } \\
\text { (L:Location, } \\
\text { N:Nature, } \\
\text { SC: Spatial Configuration, } \\
\text { P: Participants, } \\
\text { E:Environment, } \\
\text { V:Variable) }\end{array}$} & \multicolumn{2}{|c|}{ Sample } & \multicolumn{3}{|c|}{ Results } & \multirow{2}{*}{$\begin{array}{c}\text { Additional } \\
\text { Information }\end{array}$} \\
\hline & & $\begin{array}{l}\text { Collection } \\
\text { Method }\end{array}$ & Size & $\begin{array}{c}\text { Density } \\
\text { Mean/Range of Means } \\
\left.\text { (persons } / \mathrm{m}^{2}\right)\end{array}$ & $\begin{array}{c}\text { Speed } \\
\text { Mean } \\
\text { [Range of Means] } \\
\text { unless otherwise } \\
\text { specified } \\
(\mathrm{m} / \mathrm{s})\end{array}$ & $\begin{array}{l}\text { Relationship } \\
\text { Speed and } \\
\text { Density }\end{array}$ & \\
\hline
\end{tabular}

(b) Horizontal movement speeds / $\mathrm{m} \mathrm{s}^{-1}$ table heading.

Figure 3: Headings of the origin tables in the SFPE chapter [21] in 35] according to the key information.

The new data sets identified in this paper for pre-movement time, movement on the horizontal and empirical speed-density or speed-flow-relationships (movement phase) are presented in a similar form. The summary of the data as standardised format as possible is presented in App. 6 .

\section{Review process}

The intention of the review by Gwynne and Boyce was to present data of pedestrian movement in a consistent and clear manner. To achieve this, journal publications, conference proceedings and additional (publicly available, written in English and published after 1985) sources were screened. Given the manner in which the data is typically employed, results were assigned to key behavioural components derived from the engineering timeline.

As noted previously, the work by Gwynne and Boyce presents data available up to the time it was initiated (i.e. up to and including 2013) and did not provide detail on the the range of disabilities that might affect evacuation performance as this was beyond the scope of the original work. In order to supplement the chapter of Gwynne and Boyce, an extended literature review has been performed in order to update the original work and to expand the focus and generate a more inclusive engineering data resource (Fig 4). We conducted the following steps to identify the items:

1. Definition of keywords and truncated terms for search (see Appendix II).

2. Literature search of material (drafted in English) in the following sources: ScienceDirect (www.sciencedirect.com), Scopus (www.scopus.com) and ISI Web of Knowledge (www.webofknowledge.com). By using these databases, it was possible to search a large number of subject related journals such as Fire and Materials, Fire Safety Science, Fire Safety Journal or Safety Science.

3. Source publications from proceedings of the following conferences: International Symposium on Fire Safety Science (IAFSS-Symposium (https://iafss.org/symposium)), Pedestrian and Evacuation Dynamics (PED), Human Behaviour in Fire Symposium (HBiF), Interflam and Traffic and Granular Flow (TGF). 
4. Search for articles in the Journal of Fire Protection Engineering, Fire Technology, and Transportation Research Record were taken into account even if they were not listed in the research databases.

5. Lastly review, collection of relevant literature known by colleagues and from other sources reports or pre-prints, if it was publicly available.

This review process revealed 9675 results in total. After removing duplicates and screening titles in relation to relevance, 359 candidate publications remained. In a second step 178 publications were removed by screening abstracts, methods and results (see Fig 4). During the screening process we focussed on pedestrian movement, egress data and availability of data-sets. Similar to the procedure adopted by Gwynne and Boyce, we considered publications presenting results of experimental trials (hypothetical scenarios, controlled experiments, field investigations and case studies) and rejected publications dealing with with simulation studies which did not present new empirical data. Data-sets identified for this extended review comprise both the pre-movement phase and the movement phase. The data-sets predominantly refer to circulation and (non-emergency) egress following the ICE-classification [36], which describes pedestrian movement and the nature of an event by distinguishing between ingress, circulation and egress. We filtered the data according to their accordance with the original work thus removed 107 publications. Review-publications were analysed and are summarised in Sec 4. Irrespective of the data available, all remaining data sets were considered disregarding the specific data collection methods used or boundary conditions of the experimental setting. As a consequence, we cannot ensure the consistency of the conditions present during the data collection approaches or the appropriateness or validity of the methodology applied. In order to enable the user in determining the validity or suitability of the data for their application, we documented the approaches to generate the data-sets in Appendix I. Finally, we analysed the remaining 74 publications in detail. 32 of these publications contained original research and engineering egress data considering pedestrian premovement and movement of the disabled and hence, are considered in this article.

We present the data sets of the 32 publications identified in the review process in the next section. Ten of these studies are related to the pre-movement phase and 22 studies are related to the movement phase. These studies had not previously been identified by Gwynne and Boyce, will be presented. Additionally, data providing important empirical speed-density and flow-density relationships, considering pedestrians with disabilities, was analysed and is presented in Sec 4.3.

For practical reasons and, in contrast to the original paper, in this article we differentiate between three study types: announced or unannounced evacuation, experiments and training exercises. In our understanding, evacuation (announced or unannounced) were conducted to collect data and understand the dynamics of movement during the evacuation of a number of people from a real building or space. Experiments, on the other hand, are artificial situations which are carefully designed to investigate the movement of a small number of participants moving individually without interactions with other persons. If the purpose of an evacuation or a experiment was training, the term 'training exercise' is used.

\section{Results and discussion}

Overall, the extended literature review identified 74 relevant publications. 32 of these publications have original engineering egress data addressing pedestrians with disabilities supplemented by previously published review publications.

The publications were classified according to their scope as review-articles (engineering methods, clin-ical test and multidisciplinary work) or new / unknown engineering data-sets considering pedestrians with disabilities in the pre-movement and movement phase. In order to extend the original work and to give an overview on the ongoing focus of research, Table 1 summarises the review publications involving people with disabilities and mixed abilities.

We structured the review articles in three main topics: engineering, clinical and multidisciplinary. The main area 'engineering' of the review articles deals with engineering data and the implications of disab-ilities on pedestrians' movement. These reviews deal with commonly used key performance parameters e.g. unimpeded movement speed or flow constraints as well as more complex factors like route choice or 


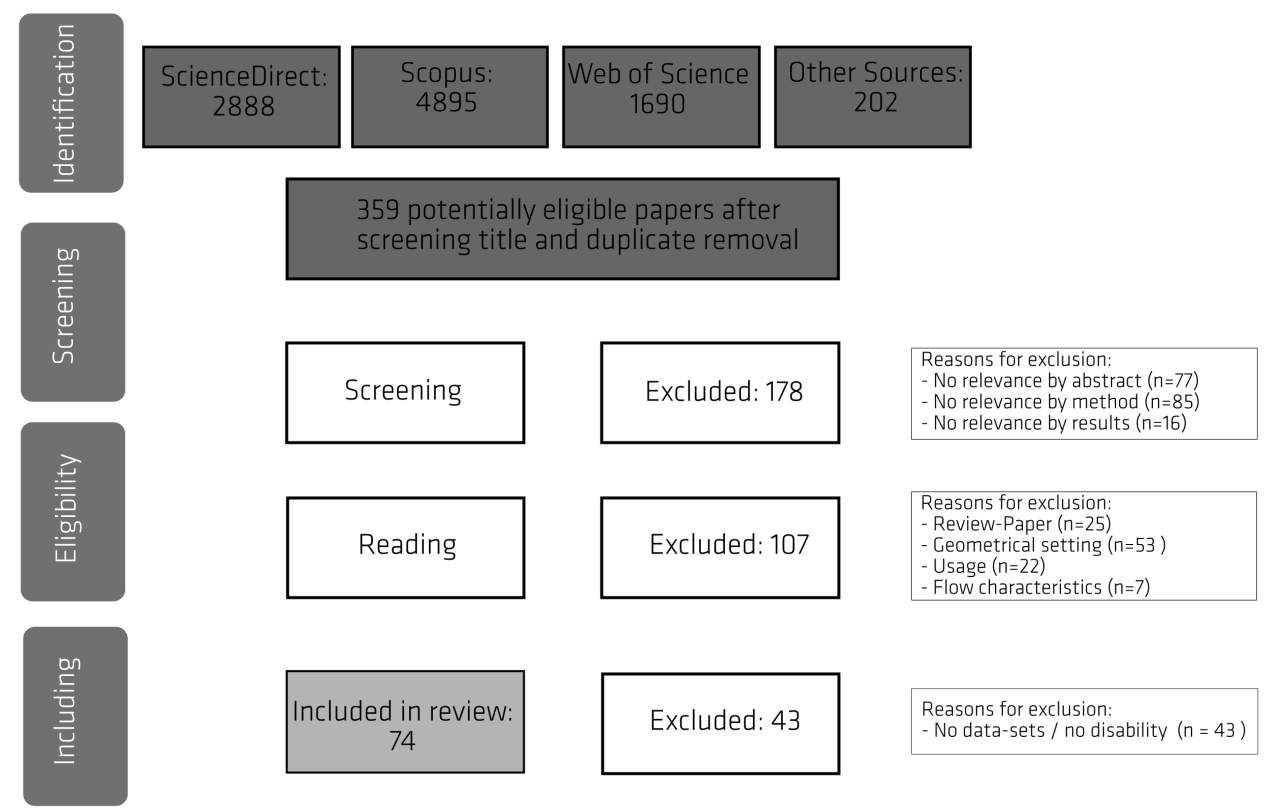

Figure 4: Methodical approach to indicate relevant publications (visualization according to [37], [38]). The review of 74 potential publications resulted in eleven additional data sets for the pre-movement and 21 additional data sets for the movement phase.

geometry-dependency. The second area 'clinical' provides an insight into studies on movement parameters in the context of clinical measurement methods. These reviews typically refer to studies that measure gait length, speed and swaying and the ability to walk over distance or time. The objective of the third area 'multidisciplinary' is to look cross-disciplinary and provide additional factors of interest for data collection, influencing factors and analysis. These three main topics constitute the starting point for updating engineering data for the pre-movement and movement phase.

Table 1: Identified thematic classification of review-articles.

\begin{tabular}{|c|c|c|}
\hline Focus & Ref & Description \\
\hline \multirow{5}{*}{ 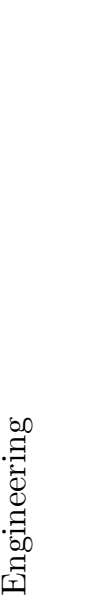 } & 39 & $\begin{array}{l}\text { Descriptive meta-analysis of normal (stratified) walking speed depending on age, } \\
\text { gender and distance }\end{array}$ \\
\hline & 40 & $\begin{array}{l}\text { Evacuation of mixed ability populations: reviews the basis for current design guidance } \\
\text { and explores the design options for persons with reduced mobility }\end{array}$ \\
\hline & 41 & $\begin{array}{l}\text { Focus on the design of the built environment and the ability of individuals with disab- } \\
\text { ilities to egress in emergency evacuations; description of the behavior of the individual } \\
\text { with a disability in response to the built environment, described almost solely by speed } \\
\text { of egress }\end{array}$ \\
\hline & 42 & $\begin{array}{l}\text { Factors important for fire evacuation in underground transportation systems and sum- } \\
\text { marise empirical research on pre-movement process, flow constraints, movement speed } \\
\text { and way finding }\end{array}$ \\
\hline & & Continued on next page \\
\hline
\end{tabular}


Table 1 - Continued from previous page

\begin{tabular}{|c|c|c|}
\hline Focus & Ref & Description \\
\hline & 43 & $\begin{array}{l}\text { Literature overview on impact of building elements (stairs, lifts, doors, corridor, } \\
\text { junction, bottleneck), population characteristics (children, disabled persons, stressed } \\
\text { groups), specific environments (aircraft, trains, etc), decision-making and information } \\
\text { processing as well as and modelling }\end{array}$ \\
\hline & 44 & Review of studies on occupants' flow characteristics \\
\hline & 21 & $\begin{array}{l}\text { Review on engineering egress data depending on evacuation phase, built environment, } \\
\text { kind of study and focussed parameter }\end{array}$ \\
\hline & 37 & $\begin{array}{l}\text { Relationship between movement ability at one point of (mid) life and cognitive decline; } \\
\text { systematic review of } 20 \text { longitudinal studies }\end{array}$ \\
\hline & 45 & $\begin{array}{l}\text { Review on pre-movement time in the built environment with influencing factors; re- } \\
\text { view on movement speeds depending on influencing factors and movement conditions; } \\
\text { movement speeds for disabled occupants }\end{array}$ \\
\hline & 13 & $\begin{array}{l}\text { Reviews the influence of demographic change and the impact of body dimensions on } \\
\text { speed and flow }\end{array}$ \\
\hline \multirow{5}{*}{ 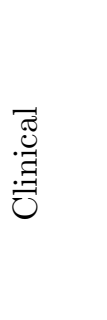 } & 46 & Acceleration of elderly patients \\
\hline & 47 & Relation between well-being and movement \\
\hline & 48 & Measurement of movement by accelerometry \\
\hline & 49 & $\begin{array}{l}\text { Collection of movement speeds linked to dependence, hospitalization, rehabilitation } \\
\text { needs, discharge locations, and ambulation category }\end{array}$ \\
\hline & 50 & Needs and challenges of occupants with cognitive disabilities in public transport \\
\hline \multirow{4}{*}{ 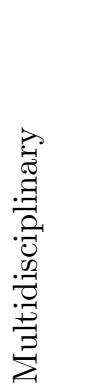 } & 51 & $\begin{array}{l}\text { Overview on the crowd motion simulation models of the last decades: cellular auto- } \\
\text { mata, social force models, velocity-based models, continuum models, hybrid models, } \\
\text { behavioural models and network models }\end{array}$ \\
\hline & 52 & $\begin{array}{l}\text { Effects of ageing on occupants' vision, hearing, physical mobility as well as cognitive } \\
\text { processes on road safety }\end{array}$ \\
\hline & 53 & $\begin{array}{l}\text { Human factors in evacuation including physical, cognitive, motivational and social } \\
\text { variables }\end{array}$ \\
\hline & 54 & State-of-the-art methods in crowd behaviour analysis inspired by physics and biology \\
\hline
\end{tabular}

\subsection{Updating engineering data for the pre-movement phase}

Although the pre-movement phase significantly influences the evacuation performance, research on this part of the engineering timeline is rarely available for occupants with disabilities or others with reduced mobility. The extended literature review revealed $(\mathrm{n}=11)$ additional publications regarding the premovement phase which had not been considered in the original work. Tab. 3 of Appendix I summarises the data collection methods, conditions and key results, as well as information relevant for the interpretation of these data-sets. Geoerg et al. [55] and Schliephake et al. [56] carried out unannounced evacuations in a sheltered-workshop and an assisted living accommodation and documented it through video capture. Premovement times of occupants with different kinds of individual or multiple disabilites and assistive devices were analysed and published by interquartile range, median and range. Hall [57] carried out evacuation experiments using different kinds of transportation methods e.g. blanket, picky-back, bed, etc. in a hospital with trained and untrained staff. The average of the preparation time is presented for each transportation method.

Hunt et al. [58], [59] carried out evacuation excercises in a hospital with trained staff assisting occupants 
with disabilities. The pre-movement time, horizontal and vertical movement speeds were determined in 32 trials with different technical assistance devices (stretcher, carry chair, evacuation chair, rescue sheet) being used by different teams. Preparation time is given by the mean and standard deviation depending on technical device and gender. MacCallum et al. [60] published data from six video-captured announced and one unannounced evacuation in different types of facilities and present preparation times (average, standard deviation, minimum, maximum) for the change from one technical device to another (e.g. from a comfortable chair to a wheelchair, a toilet to a wheelchair, etc.).

Shields et al. [61] presented the results of two unannounced evacuations in two residential homes involving twelve participants with learning disabilities. In this case pre-movement was defined as the time from alarm to the time leaving the bedroom and was provided by the interquartile range, the median and the range.

Kuligowski et al. [62], [63] and Peacock et al. [64] collected data during five announced evacuations in office and residential buildings. These activities contained 160 data points from an able-bodied group and 170 data points from participants with disabilities. Data was presented by average and standard deviation. Hoondert [65] deals with evacuation experiments under laboratory conditions in a hospital. Pre-movement times, especially uncoupling times of medical devices and times to leave room for different types of patients,e.g. dialysis, intensive care, neonatal incubator, was also presented. The influence of experience/lack of experience of the staff was displayed. A publication by Hamilton et al. [66] presents findings of twelve unannounced evacuations in primary schools in Ireland with participants in an age ranging from four to twelve years. The numbers of participants varied between each exercise between 124 to 249. The pre-movement time in this publication is defined as the time from first activation to the time the first person exits the applicable room.

Although many studies have sought to determine the pre-movement time for different populations, few have specifically addressed aspects of the pre-movement time for people with disabilities. Analysis of the available research considering occupants with disabilities suggests a wide variation in pre-movement times with time periods from seconds up to half an hour (Fig 5). This time depends on the attributes of the population which is determined by the kind of usage, e.g. many occupants in a high-rise office building are characterised by a high variance of individual characteristics. But in contrast to residential buildings, occupants are not expected to be sleeping. Fig 5 presents pre-movement times for occupants with disabilities obtained from the additional publications identified in this review.

In general, data are often subjected to highly dispersed distributions because of most occupants initiating movement within a short pre-movement time and a few occupants initiating movement after a very long pre-movement time [2], [68]. Thus, the pre-movement time is rarely normally distributed. It should be noted that supplementary assistance for occupants with disabilities may mitigate the impact of the disability and reduce the pre-movement time, while occupants with temporary or recent movement issues, who have no aid, will not have such assistance e.g. [21, Tab. 64.6].

All additional publications on occupants with disabilities described studies were carried out in formal settings with predominantly trained or instructed staff in familiar surroundings. The presence of a welldeveloped organisational setting (like in a sheltered workshop or health-care facility), availability of professional staff and extra assistance may reduce the times in the pre-movement phase [68]. Furthermore, occupants with disabilities may be aware of their own abilities and limitations and may profit from self-taught workarounds in daily life [69, Participant E]. For instance, asking a wheelchair user in one study for preparation strategies in case of emergency in daily life received the following answer: 'I will keep the mobile phone with me all the time to be prepared to get information' [70]. However, research investigating systematically this effect is rarely available.

Beyond well-developed organisational settings, individual pre-movement times of occupants with disabilities may also be increased by potential difficulties in reception, perception, response and preparation, due to the specific nature of their disabilities [5, p. $657 \mathrm{f}]$. For this reason, on the one hand, studies investigating the pre-movement phase should consider disabilities independently, e.g. a 'cognitively impaired' participant should not also be a wheelchair user because of difficulties in distinguishing the impact of the individual disabilities, to improve the statistical data base systematically. On the other hand, the combination of disabilities should be kept in mind to prevent misinterpretation and misspecification in performance-based 


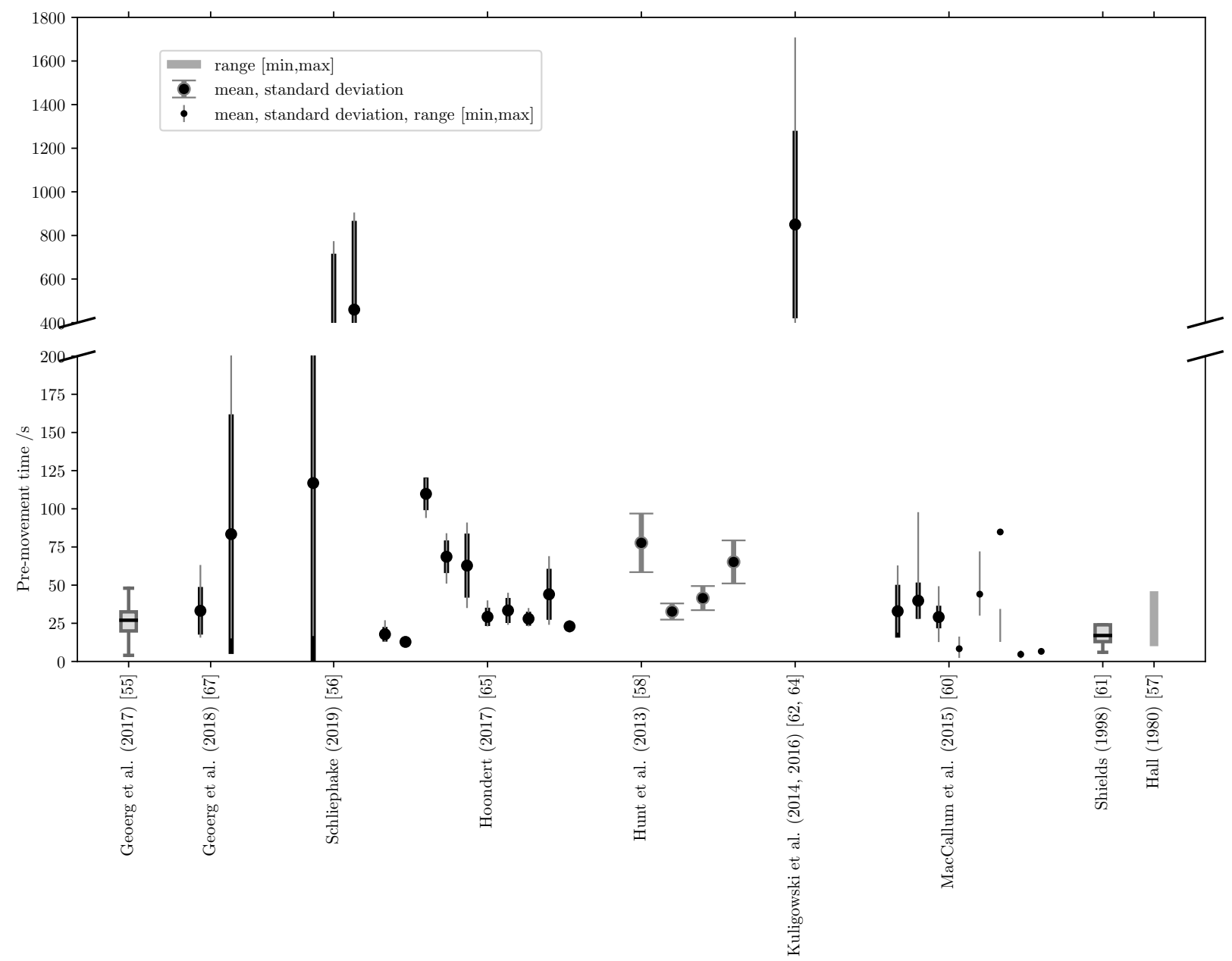

Figure 5: Pre-movement times for occupants with disabilities obtained from the additional publications (for the comprehensive data see Tab. 3). We used the following conventions to visualise different data types: the data published by [55] and [61] enables a box-and-whisker-plot with mean, interquartile range and range between minimum and maximum; the data by [58] gives mean and standard deviation represented by the gray pointplot with errorbars. Data only given by the range of minimum and maximum is represented by gray boxes, e.g. [57]. Data by [67], [56], [65], [62], [64] and [60] gives mean, standard deviation (point plot with black errorbars) and range between minimum and maximum with lightgray coloured errorbars. Please note the discontinuous axis for better visualisation of the data published by [56], [62] and [64].

design.

\subsection{Updating engineering data for the movement phase}

Numerous studies, which focus on several variables to describe the movement phase of pedestrians have been published in recent years. The publications often differentiate between the impact of geometry, e.g. junctions, or kind of movement, e.g. uni-, bi- or multi directional movement or building elements. However, few studies have considered truly heterogeneous groups or disabled pedestrians as evidenced by the small proportion of datasets presented in Gwynne and Boyce [21].

This review process, however, identified 22 additional publications focussing on unimpeded horizontal movement speed of occupants with disabilities (Fig 6).

The publication by Cabrera et al. [71] presents individual velocities of three groups of elderly participants with different ages. Movement was measured in a field study located in a public park. The impact of assistive 


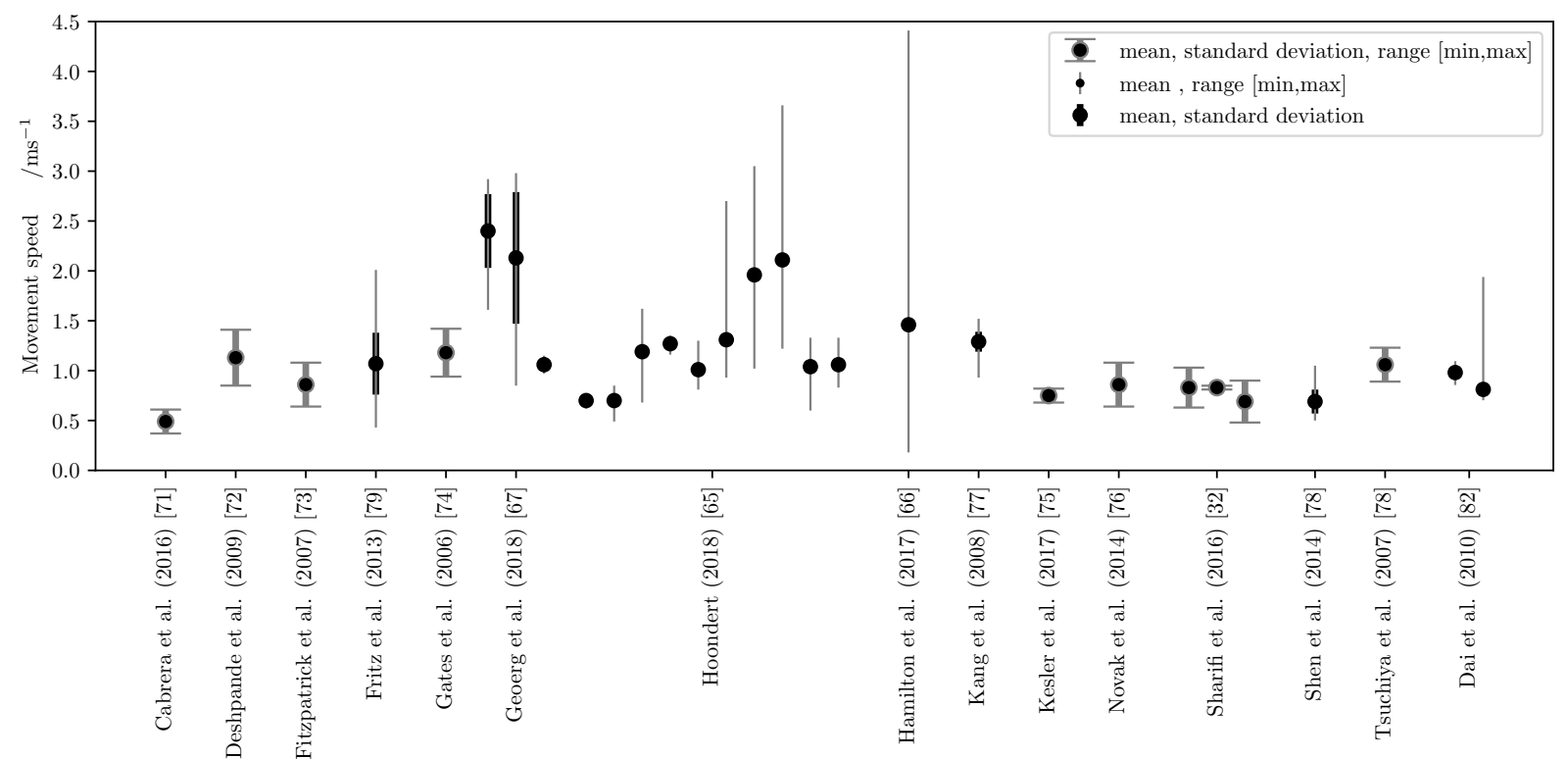

Figure 6: Selection of movement speeds regarding occupants with disabilities depending on the reviewed studies (for the comprehensive data see Tab.4). We used the following conventions to visualise different data types: the data published by [71], $[72],[73],[74],[75],[76],[32],[77]$ and [78] give mean and standard deviation represented by the gray pointplot with errorbars. Data by [79], [67], [66], [65], [80] and [81] gives mean, standard deviation (point plot with black errorbars) and range between minimum and maximum with lightgray coloured errorbars. The publication by [82] receive mean and range between minimum and maximum (black dot with gray coloured bar).

devices and grouping behaviour (group size and spatial orientation) was investigated and was compared with unimpeded walking. A publication by Hamilton et al. [66] presents horizontal movement speeds collected at 12 unannounced evacuation trainings in primary schools in Ireland with participants in an age ranging from 4-12 years. The numbers of participants varied in each exercise from 124 to 249. Deshpande et al. [72] examined walking performance presented by mental status and physical status of elderly participants. They concluded that normal walking is challenging in a neuromuscular manner while accelerated walking with simultaneous talking may be challenging with cognitive decline. Fitzpatrick et al. [73] report gait speed measured in a laboratory setting and compared the results with the cognitive function of the participants. They focus the prediction of early cognitive decline indicated by individual movement speed, but they provide also a comprehensive data set of movement speeds depending on different variables (e.g. age, gender, education, body mass index, etc.). Fritz et al. [79] investigated age-related changes in mobility and balance by backwards walking measures. For comparison, they also provided gait characteristics of forward walking (movement speed, gait length, swing percent, etc.) for different age groups. Furthermore, the variability across elderly groups is presented. The research of Kang et al. [80] compared the effect of movement speed, strength and range of motion on gait measures of young and elderly participants in a laboratory. Gates et al. [74] also presented a data set of movement speeds in a field study involving persons of different ages and gender; the effect of the group size was also investigated. Research by Novak et al.[76] presents the impact of ageing on body and segmental control of functional body parts. Kinematic data was collected from participants walking along a pathway and passing an obstacle. Movement speed, gait length and stepping frequency is compared for young and old participants. A short publication by Dai et al.[82] deals with the findings of a field study comparing movement speeds depending on age groups in public spaces of a shopping center. The impact of visibility and gender on movement speed was investigated in a controlled study in a classroom presented by Shen et al. [81]. Reduced visibility (zero or full visibility) was simulated by an eyemask and the impact on movement speed of young participants was compared to similar studies. Movement speed, depending on different visibility scenarios, were presented. Samoshin et 
al. [83] present flow-density- and velocity-density-relationships depending on the familiarity with the route and the influence of the kind of traffic facility. They considered blind and visually impaired participants in the field observations.

Walking in a group including wheelchair users was investigated by Tsuchiya et al. [78]. They compared individual unimpeded movement speed, movement speeds in homogeneous groups and movement speeds of wheelchair users in groups. Additionally, behavioural observations such as spatiotemporal needs of participants and overtaking procedures were analysed. Soong et al. [84] investigated the preferred movement speed for assessment of mobility performance of those with visual impairments. Movement speed depending on guidance by blind or seeing people for visually impaired participants was compared. Sharifi et al. [32], [77] presented findings on flow characteristics of heterogeneous pedestrian streams. Density and velocity of participants with differing categories of disabilities in a circuit of right-angles, oblique-angles, passageways and bottlenecks were collected and fundamental diagrams presented.

Kesler et al. [75] investigated the ability of persons with and without multiple sclerosis to walk along a $48 \mathrm{~m}$ path before and after a six-minute walk. More than twenty passive motion capture markers were placed on each participant to get gait parameters like step width and length. Velocity, oxygen consumption and gait width and length was compared. Jiang et al. [85] present a comparative analysis of movement speeds collected at typical observation points in hospitals and other public buildings. The impact of age and gender was investigated as well as the influence of 'healthiness/sickness'. Hoondert [65] carried out studies under laboratory conditions in a hospital. Movement speeds of different types of patients (e.g. dialysis, intensive care, neonatal incubator) were presented. The influence of the level of experience of the staff was also investigated.

Individual abilities, measurement methods and environmental conditions (e.g. age, gender, health status, motivation, facility, familiarity, time of day) influence the attainable movement speed [12], [40]. For this reason, the individual movement speeds of pedestrians on horizontal surfaces vary widely ranging from $0.3 \mathrm{~m} \mathrm{~s}^{-1}$ to $2.5 \mathrm{~m} \mathrm{~s}^{-1}[21]$, [40]. Based on the original work by Fruin ([10]), Predtechenskii and Milinski [11], Weidmann [12] and Pauls [86], international design codes and recommendations either suggest movement speeds of around $1.2 \mathrm{~m} \mathrm{~s}^{-1}[87]$, , [88] or do not provide specific values [89], [90]].

Data sets of movement speed that consider occupants with disabilities vary in comparable ranges $(0.23 \mathrm{~m} \mathrm{~s}$ ${ }^{-1}-1.95 \mathrm{~m} \mathrm{~s}^{-1}$ ). Since occupants with disabilities often use technical assistive devices (wheel-chairs, canes, sticks, crutches) or require personnel assistance, the differences in speed between occupants with and without assistive devices or assistance (by another person) may partly be explained by the need for increased coordination and concentration regarding the use of assistive devices and/or the concentration on communicating with the assistor. Individual requirements such as response capacity, familiarity and social norms may also affect the movement speed in heterogeneous groups [91], [92].

Currently, the available data are too scarce to determine the variables that effect movement speed. All research studies are a simplified version of a more complex reality and they depend on boundary conditions [93, p. 2118]. The choice of participants in movement studies, which may be limited due to ethical considerations, reduces the the number of variables for better analysis, but also leads to limited comparability among multiple studies.

\subsection{Using the flow-density or the velocity-density relationship?}

Occupants' flow and movement speeds both depend on the occupant density [94]. Hence, the flow-density or velocity-density relationships 2 are important for traffic engineering and are often used in calculation methods or for validation of such methods. The fundamental diagrams representing flow-density or velocitydensity relationships help to characterise the capacity of facilities [95].

\footnotetext{
${ }^{2}$ The terms flow-density- or the velocity-density relation means the whole data of the studies without focussing on steady states to account for the limited available data.
} 
Both relationships depend on various variables like building type, cultural $([96])$ or gender $([12])$ impacts and socio-demographic factors. A considerable amount of research has been attempted to develop the flowdensity or velocity-density relationships. This research has focussed mainly on different building types and variations in geometries such as bottlenecks, stairs and corridors as well as the influence of different flow types (uni- and bidirectional (e.g. [97], [98], [99], [100], [101], [102], [30], [28]), merging (e.g. [103]), transition (e.g. [100]) and crossing (e.g. [104])).

Fundamental diagrams considering participants with disabilities or heterogeneous populations are rare. Fig 7 compares the flow-density and velocity-density relationship of unidirectional movement determined in studies involving people with disabilities to the fundamental diagram. Note that the focus and methods differ among the publications: e.g. [98] used a towel fastened in front of the face to simulate a vision loss of participants, whilst [105] compared the relationship of velocity and flow on a stairway in front and behind a wheelchair user in an unannounced evacuation. The disabilities represented in currently available flowdensity and velocity-density relationships can be classified as 'blind/visually impaired', 'age-related impact' and 'usage of assistive devices'.

Guo et al. [98] analysed the impact of reduced visibility conditions on uni- and bidrectional flow. They reported a reduced flow for both settings. Samoshin et al. [83] investigated the characteristics of blind and visually impaired people. Flow data for different types of route (horizontal, incline and door) and the influence of familiarity are presented. The publication by Sørensen et al. [106], [107] reports an effect of vision loss on movement speed. A strong influence of density-indicated decrease of individual velocity is reported. Results from an evacuation study with pre-school participants were reported by Kholshevnikov [108]. This study was designed as an extension of the empirical database of Predtechenskii and Milinskii [11]. Another publication by Kholshevnikov et al. [109] reports findings from evacuation studies of elderly occupants at a senior citizen health care building. The impact of using different assistive devices was analysed and a decreased velocity was reported when participants used assistive devices. Larusdottir et al.[110], [111] and [112] report the flow of children aged from zero to two and three to six years through a narrowing corridor. They report a tendency to higher flows for children moving groups than the reference data for adults.

Shields et al. [105] examined the relationship between location of occupants in relation to wheelchair users and attainable movement speed during an unannounced evacuation. They reported a much greater mean movement speed ahead of wheelchair users, because participants following the wheelchair users tended to treat it as a slowly moving obstruction. A remarkable reluctance for overtaking wheelchair users during the unannounced evacuation was reported. Tsuchiya et al. [78] investigated the influence of the ratio of wheelchair users in a population and the width of an opening. The distribution of walking speeds for participants using wheelchairs is compared against the movement speed of non-disabled participants. Furthermore, the relationship between individual movement and moving in groups is presented.

Sharifi et al. [77] present results from large-scale studies considering visually impaired participants, motorised and -non-motorised-wheelchair users and participants without disabilities. They present individual movement speed, density and flow for movement in the horizontal, incline, corner, bottleneck and stair configurations. The resulting fundamental diagrams were based on the Kladek-equation [113, p. 89] (mostly known by Weidmann [12, p. 54]):

$$
v_{i}=v_{0} \cdot\left(1-\exp \left(\gamma \cdot\left(\frac{1}{\rho}-\frac{1}{\rho_{\max }}\right)\right)\right.
$$

With

$$
\begin{array}{ll}
v_{0} & =\text { unimpeded (free) movement speed } \\
\gamma & =\text { calibration constant } \\
\rho_{\max } & =\text { jam density }
\end{array}
$$



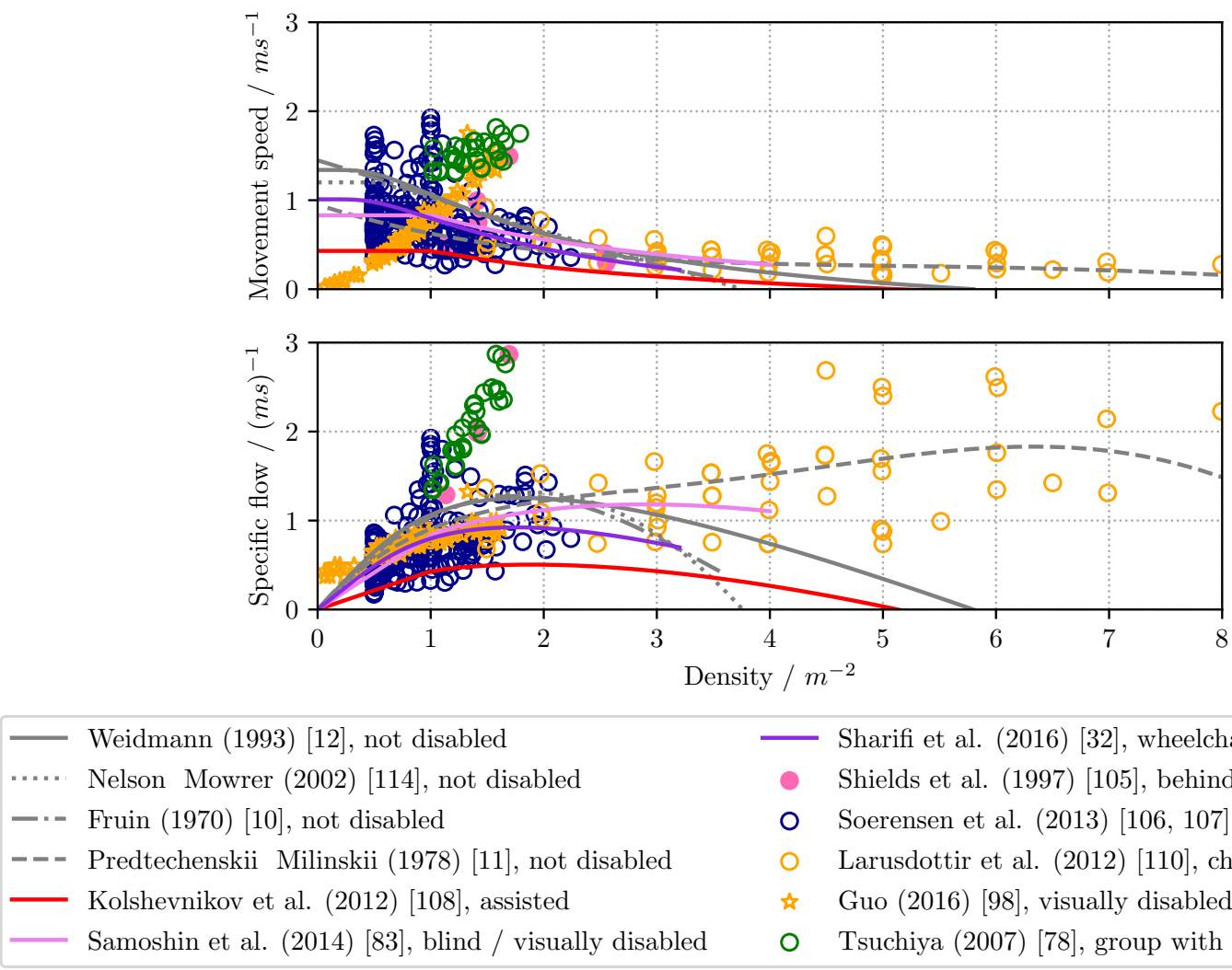

Sharifi et al. (2016) [32], wheelchair
Shields et al. (1997) [105], behind wheelchair
○ Soerensen et al. (2013) [106, 107], visually disabled
Larusdottir et al. (2012) [110], children
○ Guo (2016) [98], visually disabled
Tsuchiya (2007) [78], group with wheelchairs

Figure 7: Velocity-density (top) and flow-density-relationship (bottom) of pedestrian movement through a bottleneck considering pedestrians with disabilities compared to the frequently referenced fundamental diagrams by [12], [114], [10] and [11] (with $\left.f=0.113 \mathrm{~m}^{2}\right)$.

Empirical data represent are collected from publications by: [108], [83], [32], [105], [106]/[107], [110], [98], [78]. Data picked up with Web plot digitalizer by the authors from publication. We refer the reader to Table 5 in App 6 for comprehensive details on data collection and measurement methods.

Overall, the consideration of occupants with disabilities further increases the number of variables which are important for flow-density and velocity-density relationships; for instance, the use of different devices to mitigate the impact of an impairment. Different kind of disabilities in heterogeneous groups may lead to interactions, fluctuations and transitions between different 'conditions of movement'. Social behaviour in groups, difficulties in accelerating/decelerating of individuals and the fact that some may occupying larger areas and might require more space (e.g. because of wheelchairs or crutches) become more important [91]. The type and severity of disability can have different effects on the movement, e.g. the movement of a blind person in a crowded place may be impeded by others [115] whilst the presence of a blind person assisted by a white cane may impede neighbours movement. The movement of a wheelchair user, on the other hand, may be unimpeded in low population densities (as exemplified in Fig 8). It should also be noted that different impairments may impede an individual's capacity to adapt to changing conditions around them. For instance, a wheelchair user may maintain comparable travel speeds to individuals without an impairment in clear welldefined spaces. However, their capacity to navigate around local obstacles or nearby occupants movement may be more restricted.

Notwithstanding, the analysis of the flow-density and velocity-density relations for occupants with disabilities confirm two important results: first, similar to the relations of populations without impairments, higher movement speeds are observed at low population densities, and second, the maximum flow seems to depend on the individual movement speed. 


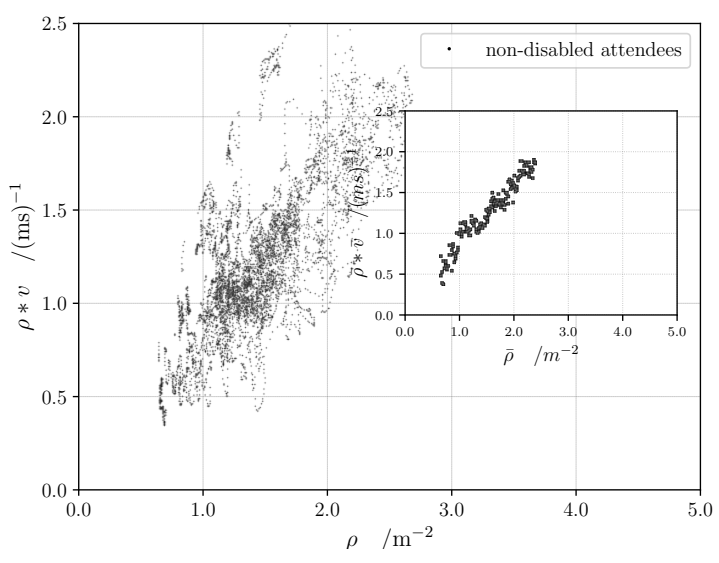

(a) Flow-density-relation of movement through a corridor without participation of participants with disabilities.

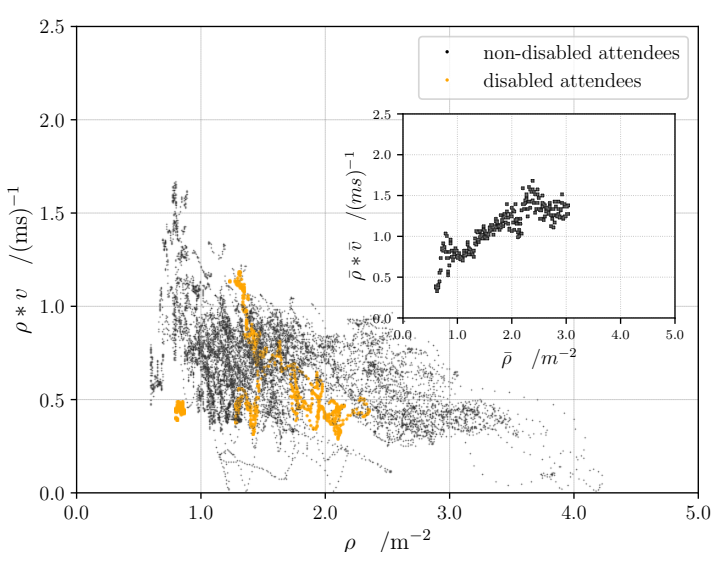

(b) Flow-density-relation of movement through a corridor with participation of participants with disabilities.

Figure 8: Individual fundamental diagram (Flow $\left(J_{s}=\rho \cdot v\right)$-density-relation for horizontal movement through a corridor with a width of $0.9 \mathrm{~m}$ ) of a group without any disabled participants (left) and with $\approx 10 \%$ wheelchair users (right). Movement in heterogenous groups is often characterised by high flucutuation, phase transitions and interactions. Source: [91.

It is important to note that most of the observations focus on densities of $\rho \leq 2 \mathrm{~m}^{-2}$. Furthermore, the studies differ in their measurement methods and environmental conditions (see Table 5 in Appenidx I). The users of such data should be aware that the quantities of the functional relationship are highly sensitive to the user definition and the measurement methods used. For a comprehensive discussion on this issue, we refer to [116], [117]. Besides, the consideration of occupants with disabilities in high population densities adds additional challenges to the realisation of studies on movement (e.g. technical ability to collect the data, ethical concerns with the well-being of those involved and/or the number of factors that influence the results produced). Social norms, individual behaviour and ordering effects in movement as well as the influence of technical assistive devices and accompanying persons may impact individual movement and, if there is insufficient room for overtaking, may slow down the rest of the population [91]. Technical asssitive devices like evacuation chairs or buddy systems for pre-identified persons with physical-, mental- or age-related disability may be perceived as constraints to movement [118, p. 159].

\section{Conclusion}

A significant proportion (approximately $20 \%$ ) of people in most industrial societies has a disability and this percentage is likely to increase in the future given current demographic trends relating to ageing and obesity [119], [22]. Together with increased accessibility, this means that building populations are becoming more and more diverse with a wider variety of movement abilities, i.e. it is no longer safe to assume that they only comprise able-bodied and fit individuals ([120], [121], [40]).

This paper has presented an extensive update on the comprehensive review given by [21] with focus on engineering data for the pre-movement and movement phase for occupants with physical-, mental- or agerelated disabilities and reduced performance. It identifies differences for the design calculation and prediction of key values for egress if individual characteristics of individuals in a heterogeneous groups are taken into account.

The influence of disabilities is not confined to movement; some disabilities may have a more complex impact, e.g. obesity on stability [16] and individual space requirement [13] and a reduced movement speed [122] or cognitive disability on memory and gait speed [123]. Multiple factors may influence performance and little is known about the interaction between such factors, e.g. device, weight, age, terrain, etc. In addition, the presence of persons with impairments may have a physical and social impact on others around 
them. Furthermore, there is a lack of data regarding the impact of the use of technical assistive devices, such as canes, crutches, wheelchairs, white stick, etc., and also the impact of the absence of such devices on movement. Whilst data exists related to access in relation to the static space requirements of people using assistive devices, e.g. in codes and standards, little data exists in relation to the space needed during movement, e.g. that of a crutch user or a user of a walking frame in taking a step forward in a crowd, and the impact on movement characteristics like gait length or frequency. Even if no physical assistance is needed, the likelihood that a person with a disability may be accompanied by others has until now rarely been considered in engineering calculations relating to movement.

This paper has reviewed the limited data related to occupants with disabilities and reduced performance that might be used in engineering evacuation calculation. It continues pioneering works on this topic by [21] and [40] and presents some new data sets and derived relationships. It is an attempt to highlight current challenges in considering mixed populations in the design of sufficient egress and the impact of expected demographic changes on egress performance. Design rules regarding capacities or flows generally assume relatively uniform and capable populations derived from data on largely unimpaired occupants [21]. It is therefore important to understand the impact of disabilities on pre-movement and movement. The supply in evacuation methods for this is certainly a challenge and focus should be on developing an understanding of movement of heterogeneous populations and quantify performance values in a form that can be used by practising fire safety engineers in analysis of buildings using a performance based approach.

\section{Authors' contributions}

PG, SG, KB, SH and FB carried out the problem identification and developed the method for the selection and evaluation of relevant material for the contribution. PG and FB carried out the analysis. PG and FB drafted the manuscript. SG, SH, KB and AB suggested modifications in the manuscript critically revising its content. All authors read and approved the final manuscript.

\section{Acknowledgements}

Part of this work has been performed within the research program Safety for people with physical, mental or age-related disabilities (SiME) supported by the German Federal Ministry of Education and Research BMBF (grant numbers 13N13946 and 13N13950). The authors want to thank the two anonymous reviewers for enhancing the quality of this paper.

PG thanks the SFPE Foundation for financial support with the Dr. Guylène Proulx, OC Scholarship.

\section{References}

[1] J. Pauls, Calculating evacuation times for tall buildings, Fire Safety Journal 12 (1987) 213-236.

[2] Gwynne, Steven M. V., E. Kuligowski, M. Spearpoint, E. Ronchi, Bounding defaults in egress models, Fire and Materials (2013) 335-352.

[3] M. J. Hurley, E. R. Rosenbaum, Performance-Based Design, in: M. J. Hurley (Ed.), SFPE handbook of fire protection engineering, Springer, New York, 2016, pp. 1233-1260.

[4] SFPE Task Group on Human Behavior in Fire, Guide to Human Behaviour in Fire: Engineering Guide: 1st Draft Public Comment Version, 2017.

[5] E. D. Kuligowski, Gwynne, Steven M. V., M. J. Kinsey, L. Hulse, Guidance for the Model User on Representing Human Behavior in Egress Models, Fire Technology 53 (2017) 649-672.

[6] E. Ronchi, Testing the predictive capabilities of evacuation models for tunnel fire safety analysis, Safety Science 59 (2013) 141-153.

[7] E. Ronchi, E. D. Kuligowski, D. Nilsson, R. D. Peacock, P. A. Reneke, Assessing the Verification and Validation of Building Fire Evacuation Models, Fire Technology (2014).

[8] B. D. Hankin, R. A. Wright, Passenger Flow in Subways, Operational Research Societys Open Conference 9 (1958) 81.

[9] D. Oeding, Verkehrsbelastung und Dimensionierung von Gehwegen und anderen Anlagen des Fussgängerverkehrs, volume 22 of Strassenbau und Strassenverkehrstechnik, Bundesminister für Verkehr, Abt. Strassenbau, Bonn, 1963.

[10] J. J. Fruin, Pedestrian planning and design, Metropolitan Association of Urban Designers and Environmental Planners, New York, 1971. 
[11] V. M. Predtechenskii, A. I. Milinskii, Personenströme in Gebäuden: Berechnungsmethoden für die Projektierung, Staatsverlag der Deutschen Demokratischen Republik, Berlin and Ger., 1971.

[12] U. Weidmann, Transporttechnik der Fussgänger, Transporttechnische Eigenschaften des Fussgängerverkehrs Literaturauswertung, Zürich, IVT, Institut für Verkehrsplanung, Transporttechnik, Strassen- und Eisenbahnbau, 1992. doi $10.3929 /$ ethz-a-000687810

[13] P. Thompson, D. Nilsson, K. Boyce, D. McGrath, Evacuation models are running out of time, Fire Safety Journal 78 (2015) 251-261.

[14] United Nations, World Population Prospects: The 2015 Revision: Comprehensive Tables, 2015. URL: http://esa.un. org/unpd/wpp/

[15] Organisation for Economic Cooperation and Development, Obesity Update, June 2014. URL: http://www.oecd.org/ health/Obesity-Update-2014.pdf.

[16] M. Forhan, S. V. Gill, Obesity, functional mobility and quality of life, Best practice \& research. Clinical endocrinology \& metabolism 27 (2013) 129-137.

[17] Statistisches Bundesamt, Behinderte Menschen: Schwerbehinderte Menschen am Jahresende, 2013. URL: https://www . destatis.de/DE/ZahlenFakten/GesellschaftStaat/Gesundheit/Behinderte/Tabellen/GeschlechtBehinderung.html; jsessionid=E203D25B5707C218C448D62674324A5A.cae2

[18] W. Erickson, C. Lee, S. von Schrader, Disability Statistics from the American Community Survey (ACS): Retrieved from Cornell University Disability Statistics website: www.disabilitystatistics.org, 2018. URL: http://www. disabilitystatistics.org/reports/acs.cfm?statistic=1

[19] W. He, Larsen, Luke, J., ACS-29, Older Americans With a Disability: 2008-2012, 2014. URL: https://www.census.gov/ content/dam/Census/library/publications/2014/acs/acs-29.pdf

[20] R. Fahy, Panel: Life safety options for people with disabilities - how far have we come?, Fire and Materials 39 (2015) $475-485$.

[21] S. Gwynne, K. E. Boyce, Engineering Data, in: M. J. Hurley (Ed.), SFPE handbook of fire protection engineering, Springer, New York, 2016, pp. 2429-2551.

[22] United Nations, World Population Prospects: The 2017 Revision: Comprehensive Tables, 2017. URL: https://www.un. org/development/desa/publications/world-population-prospects-the-2017-revision.html

[23] E. D. Kuligowski, Human Behavior in Fire, in: M. J. Hurley (Ed.), SFPE handbook of fire protection engineering, Springer, New York, 2016, pp. 2070-2114.

[24] Candy, M. Y. Ng, W. K. Chow, A Brief Review on the Time Line Concept in Evacuation, International Journal on Architectural Science 7 (2006) 1-13.

[25] British Standards Institution, PD 7974-6: The Application of Fire Safety Engineering Principles to Fire Safety Design of Buildings Part 6: Human Factors: Life Safety Strategies, Occupancy Evacuation, Behaviour and Condition (Sub-System 6), 2004.

[26] International Organization for Standardization, Fire-safety engineering -Technical information on methods for evaluating behaviour and movement of people, 2009.

[27] E. Kuligowski, Burning Down the Silos: Integrating new perspectives from the social sciences into human behavior in fire research, Fire and Materials 41 (2017) 389-411.

[28] A. Seyfried, B. Steffen, W. Klingsch, M. Boltes, The fundamental diagram of pedestrian movement revisited, Journal of Statistical Mechanics: Theory and Experiment 2005 (2005) P10002.

[29] W. Daamen, S. P. Hoogendoorn, Flow-Density Relations for Pedestrian Traffic, in: A. Schadschneider, R. Kühne, T. Pöschel, M. Schreckenberg, D. E. Wolf (Eds.), Traffic and Granular Flow'05, Springer-Verlag Berlin Heidelberg, Berlin, Heidelberg, 2007, pp. 315-322. doi 10.1007/978-3-540-47641-2\{\textunderscore\}27

[30] A. Seyfried, O. Passon, B. Steffen, M. Boltes, T. Rupprecht, W. Klingsch, New Insights into Pedestrian Flow Through Bottlenecks, Transportation Science 43 (2009) 395-406.

[31] A. Seyfried, A. Schadschneider, Empirical results for pedestrian dynamics and their implications for modeling, Networks and Heterogeneous Media 6 (2011) 545-560.

[32] M. S. Sharifi, D. Stuart, K. Christensen, A. Chen, Traffic Flow Characteristics of Heterogeneous Pedestrian Stream Involving Individuals with Disabilities, Transportation Research Record: Journal of the Transportation Research Board 2537 (2015) 111-125.

[33] E. Bosina, U. Weidmann, Generic Description of the Pedestrian Fundamental Diagramm, in: W. Song, J. Ma, L. Fu (Eds.), Proceedings of the 8th International Conference on Pedestrian and Evacuation Dynamics, 2016, pp. 548-555.

[34] International Organization for Standardization, Fire safety - Vocabulary, 2017.

[35] M. J. Hurley (Ed.), SFPE handbook of fire protection engineering, fifth edition ed., Springer, New York, 2016.

[36] S. Gwynne, E. D. Kuligowski, Simulating a Building as a People Movement System, Journal of Fire Sciences 27 (2009) $343-368$.

[37] L. H. J. Kikkert, N. Vuillerme, J. P. van Campen, T. Hortobágyi, C. J. Lamoth, Walking ability to predict future cognitive decline in old adults: A scoping review, Ageing research reviews 27 (2016) 1-14.

[38] D. A. Field, W. C. Miller, S. E. Ryan, T. Jarus, A. Abundo, Measuring Participation for Children and Youth With Power Mobility Needs: A Systematic Review of Potential Health Measurement Tools, Archives of physical medicine and rehabilitation 97 (2016) 462-477.e40.

[39] R. W. Bohannon, A. Williams Andrews, Normal walking speed: a descriptive meta-analysis, Physiotherapy 97 (2011) $182-189$.

[40] K. Boyce, Safe evacuation for all - Fact or Fantasy? Past experiences, current understanding and future challenges, Fire Safety Journal (2017). 
[41] K. Christensen, S. Collins, J. Holt, C. Phillips, The Relationship Between the Design of the Built Environment and the Ability to Egress of Individuals with Disabilities, Journal of Disability Policy Studies 2 (2007) 24-35.

[42] K. Fridolf, D. Nilsson, H. Frantzich, Fire Evacuation in Underground Transportation Systems: A Review of Accidents and Empirical Research, Fire Technology 49 (2013) 451-475.

[43] D. Greenwood, S. Sharma, A. Johansson, Gap Analysis of Current Industrial Challenges and the State-of-the-Art in Pedestrian Modelling, Transportation Research Procedia 2 (2014) 219-227.

[44] A. Gupta, N. Pundir, Pedestrian Flow Characteristics Studies: A Review, Transport Reviews 35 (2015) 445-465.

[45] L. Shi, Q. Xie, X. Cheng, L. Chen, Y. Zhou, R. Zhang, Developing a database for emergency evacuation model, Building and Environment 44 (2009) 1724-1729.

[46] V. H. Cheung, L. Gray, M. Karunanithi, Review of accelerometry for determining daily activity among elderly patients, Archives of physical medicine and rehabilitation 92 (2011) 998-1014.

[47] A. C. Gatrell, Therapeutic mobilities: walking and 'steps' to wellbeing and health, Health \& Place 22 (2013) 98-106.

[48] A. Godfrey, R. Conway, D. Meagher, G. OLaighin, Direct measurement of human movement by accelerometry, Medical engineering \& physics 30 (2008) 1364-1386.

[49] S. Fritz, M. Lusardi, White Paper: "Walking Speed: the Sixth Vital Sign", Journal of Geriatric Physical Therapy 32 (2009) $2-5$.

[50] R. Risser, E. M. Lexell, D. Bell, S. Iwarsson, A. Ståhl, Use of local public transport among people with cognitive impairments - A literature review, Transportation Research Part F: Traffic Psychology and Behaviour 29 (2015) 83-97.

[51] D. C. Duives, W. Daamen, S. P. Hoogendoorn, State-of-the-art crowd motion simulation models, Transportation Research Part C: Emerging Technologies 37 (2013) 193-209.

[52] G. Dunbar, C. A. Holland, E. A. Maylor, Road Safety Research Report No. 37: Older Pedestrians: A Critical Review of the Literature, 2004.

[53] G. Hofinger, R. Zinke, L. Künzer, Human Factors in Evacuation Simulation, Planning, and Guidance, Transportation Research Procedia 2 (2014) 603-611.

[54] V. J. Kok, M. K. Lim, C. S. Chan, Crowd behavior analysis: A review where physics meets biology, Neurocomputing 177 (2016) 342-362.

[55] P. Geoerg, R. Block, W. Heister, S. Holl, A. Pulm, A. Hofmann, A score regarding the need for assistance: Considering pedestrians with disabilities in evacuation planning, in: U. Krause, M. Rost (Eds.), Proceedings of the 5th Magdeburg Fire and Explosion Prevention Day, 2017.

[56] L. Schliephake, P. Geoerg, S. Holl, A. Hofmann, Pre-evacuation Data Collected from an Evacuation Training in an Assistive Living, 2019.

[57] J. Hall, Patient Evacuation in Hospitals, in: D. Canter (Ed.), Fires and human behaviour, Wiley-\&-Sons, Chichester, 1980, pp. 203-225.

[58] A. Hunt, E. R. Galea, P. J. Lawrence, An analysis and numerical simulation of the performance of trained hospital staff using movement assist devices to evacuate people with reduced mobility, Fire and Materials (2013) 407-429.

[59] A. Hunt, E. R. Galea, P. J. Lawrence, An analysis and numerical simulation of the performance of trained hospital staff using movement assist devices to evacuate people with reduced mobility, Fire and Materials 39 (2015) 407-429.

[60] C. MacCallum, P. Lennon, R. Lennon, An investigation and analysis of pre-movement and evacuation, times, procedures and behaviours in irish health sector buildings, in: K. E. Boyce (Ed.), Proceedings of the 6th international Symposium on Human Behaviour in Fire, 2015, pp. 501-512.

[61] T. J. Shields, B. SMYTH, K. E. Boyce, G. W. H. Silcock, Evacuation behaviours of occupants with learning difficulties in residential homes, in: T. J. Shields (Ed.), Proceedings of the first international symposium on human behaviour in fire, 1998, pp. 369-377.

[62] E. D. Kuligowski, R. D. Peacock, P. K. Reneke, E. Weiss, C. R. Hagwood, K. J. Overholt, R. P. Elkin, J. D. Averill, E. Ronchi, B. L. Hoskins, M. Spearpoint, Movement on Stairs During Building Evacuations: NIST Technical Note 1839, National Institute of Standards and Technology, 2014. doi 10.6028/NIST.TN.1839

[63] E. Kuligowski, R. Peacock, E. Wiess, B. Hoskins, Stair evacuation of people with mobility impairments, Fire and Materials 39 (2015) 371-384.

[64] R. D. Peacock, P. A. Reneke, E. D. Kuligowski, C. R. Hagwood, Movement on Stairs During Building Evacuations, Fire Technology (2016).

[65] P. Hoondert, State of the art fire safety concept for evacuation of different types of vulnerable patients in Dutch hospitals, Masters Thesis, Delft University of Technology, Delft, The Netherlands, 2017.

[66] G. N. Hamilton, P. F. Lennon, J. O'Raw, J. O'Raw, Human behaviour during evacuation of primary schools: Investigations on pre-evacuation times, movement on stairways and movement on the horizontal plane, Fire Safety Journal 91 (2017) 937-946.

[67] P. Geoerg, R. M. Polzin, J. Schumann, S. Holl, A. Hofmann, Small-scale Studies on Evacuation Characteristics of Pedestrians with physical, mental or age-related Disabilities, Journal of Physics: Conference Series 1107 (2018) 072006.

[68] S. Gwynne, D. L. Boswell, G. Proulx, Understanding the Effectiveness of Notification Technologies in Assisting Vulnerable Populations, Journal of Fire Protection Engineering 19 (2009) 31-49.

[69] K. Butler, E. Kuligowski, S. Furman, R. Peacock, Perspectives of occupants with mobility impairments on evacuation methods for use during fire emergencies, Fire Safety Journal 91 (2017) 955-963.

[70] L. Künzer, R. Zinke, Ergebnisse der Befragung von besonderen Personengruppen zu Wissen und Verhalten in Gefahrensituationen: Begleitstudie zur SiME-Parameterstudie vom 10. Juni 2017: Projektinternes Memorandum Nr. 17, 2017.

[71] F. Cabrera, F. Munoz, C. Perez, Walking Patterns of Elderly in a Peruvian Public Space, in: W. Song, J. Ma, L. Fu (Eds.), Proceedings of the 8th International Conference on Pedestrian and Evacuation Dynamics, 2016, pp. 12-17. 
[72] N. Deshpande, E. J. Metter, S. Bandinelli, J. Guralnik, L. Ferrucci, Gait speed under varied challenges and cognitive decline in older persons: a prospective study, Age and ageing 38 (2009) 509-514.

[73] A. L. Fitzpatrick, C. K. Buchanan, R. L. Nahin, S. T. Dekosky, H. H. Atkinson, M. C. Carlson, J. D. Williamson, Associations of gait speed and other measures of physical function with cognition in a healthy cohort of elderly persons, The journals of gerontology. Series A, Biological sciences and medical sciences 62 (2007) 1244-1251.

[74] T. Gates, D. Noyce, A. Bill, N. van Ee, Recommended Walking Speeds for Timing of Pedestrian Clearance Intervals Based on Characteristics of the Pedestrian Population, Transportation Research Record: Journal of the Transportation Research Board 1982 (1986) 38-47.

[75] R. M. Kesler, A. E. Klieger, M. K. Boes, E. T. Hsiao-Wecksler, R. E. Klaren, Y. Learmonth, R. W. Motl, G. P. Horn, Egress Efficacy of Persons with Multiple Sclerosis During Simulated Evacuations, Fire Technology 26 (2017) 2286.

[76] A. C. Novak, N. Deshpande, Effects of aging on whole body and segmental control while obstacle crossing under impaired sensory conditions, Human movement science 35 (2014) 121-130.

[77] M. S. Sharifi, D. Stuart, K. Christensen, A. Chen, Y. S. Kim, Y. Chen, Analysis of Walking Speeds Involving Individuals with Disabilities in Different Indoor Walking Environments, Journal of Urban Planning and Development 142 (2016) 04015010 .

[78] S. Tsuchiya, Y. Hasemi, Y. Furukawa, Evacuation Characteristics Of Group With Wheelchair Users, Proceedings of the Asia-Oceania Symposium on Fire Science and Technology (2007).

[79] N. E. Fritz, A. M. Worstell, A. D. Kloos, A. B. Siles, S. E. White, D. A. Kegelmeyer, Backward walking measures are sensitive to age-related changes in mobility and balance, Gait \& posture 37 (2013) 593-597.

[80] H. G. Kang, J. B. Dingwell, Effects of walking speed, strength and range of motion on gait stability in healthy older adults, Journal of biomechanics 41 (2008) 2899-2905.

[81] Y. Shen, Q.-s. Wang, W.-g. Yan, J.-h. Sun, K. Zhu, Evacuation Processes of Different Genders in Different Visibility Conditions: An Experimental Study, Procedia Engineering 71 (2014) 65-74.

[82] B. Q. Dai, T. Wang, J. Zhang, Study on Emergency Evacuation Ability of Exits in Public Assembly Places, Applied Mechanics and Materials 29-32 (2010) 2540-2543.

[83] D. Samoshin, R. Istratov, The Characteristics of Blind and Visually Impaired People Evacuation in Case of Fire, Fire Safety Science 11 (2014) 1160-1169.

[84] G. P. Soong, J. E. Lovie-Kitchin, B. Brown, Preferred walking speed for assessment of mobility performance: sighted guide versus non-sighted guide techniques, Clinical and Experimental Optometry 83 (2000) $279-282$.

[85] Z.-m. Jiang, P.-h. Zhang, R.-x. Shang, X.-l. Tian, Investigation and Simulation on Human Evacuation Behaviour in Large Hospital Building in Shenyang, Procedia Engineering 71 (2014) 101-106.

[86] J. Pauls, Movement of people, in: P. J. DiNenno (Ed.), SFPE handbook of fire protection engineering, National Fire Protection Association and Society of Fire Protection Engineers, Quincy (Mass.) and Boston, 1995.

[87] British Standards Institution, Application of fire safety engineering principles to the design of buildings, 2002.

[88] RiMEA e.V., Guideline for Microscopic Evacuation Analysis (RiMEA): Version: 3.0.0, 2016.

[89] International Organization for Standardization, Fire safety engineering - Selection of design occupant behavioural scenarios, 2015.

[90] Australian Government, State and Territories of Australia (Ed.), International fire engineering guidelines, edition 2005 ed., ABCB for the Australian Government State and Territories of Australia, Canberra A.C.T., 2005.

[91] P. Geoerg, J. Schumann, M. Boltes, S. Holl, A. Hofmann, The influence of physical and mental constraints to a pedestrian stream through a bottleneck, in: A. S. Dederichs (Ed.), 9th Conference on Pedestrian and Evacuation Dynamics, Lund, Sweden, 2018.

[92] A. Sieben, J. Schumann, A. Seyfried, Collective phenomena in crowds-Where pedestrian dynamics need social psychology, PloS one 12 (2017) e0177328.

[93] Gwynne, Steven M. V., E. R. Rosenbaum, Employing the Hydraulic Model in Assessing Emergency Movement, in: M. J. Hurley (Ed.), SFPE handbook of fire protection engineering, Springer, New York, 2016, pp. 2115-2151. doi 10.1007/ 978-1-4939-2565-0\{\textunderscore\}59.

[94] A. Seyfried, M. Boltes, J. Kähler, W. Klingsch, A. Portz, T. Rupprecht, A. Schadschneider, B. Steffen, A. Winkens, Enhanced Empirical Data for the Fundamental Diagram and the Flow Through Bottlenecks, in: W. Klingsch, C. Rogsch, A. Schadschneider, M. Schreckenberg (Eds.), Pedestrian and Evacuation Dynamics 2008, Springer Berlin Heidelberg, Berlin and Heidelberg, 2010, pp. 145-156. doi 10.1007/978-3-642-04504-2\{\textunderscore\}11

[95] L. D. Vanumu, K. Ramachandra Rao, G. Tiwari, Fundamental diagrams of pedestrian flow characteristics: A review, European Transport Research Review 9 (2017) 1753.

[96] U. CHATTARAJ, A. Seyfried, P. CHAKROBORTY, Comparison of Pedestrian Fundamental Diagram Across Cultures, Advances in Complex Systems 12 (2009) 393-405.

[97] S. Holl, Methoden für die Bemessung der Leistungsfähigkeit multidirektional genutzter Fußverkehrsanlagen, Dissertation, Bergische Universität, Wuppertal, 2016.

[98] N. Guo, Q.-Y. Hao, R. Jiang, M.-B. Hu, B. Jia, Uni- and bi-directional pedestrian flow in the view-limited condition: Experiments and modeling, Transportation Research Part C: Emerging Technologies 71 (2016) 63-85.

[99] J. Zhang, W. Klingsch, A. Schadschneider, A. Seyfried, Ordering in bidirectional pedestrian flows and its influence on the fundamental diagram (2011).

[100] J. Zhang, W. Klingsch, A. Schadschneider, A. Seyfried, Transitions in pedestrian fundamental diagrams of straight corridors and T-junctions, Journal of Statistical Mechanics: Theory and Experiment 2011 (2011) P06004.

[101] J. Zhang, A. Seyfried, Comparison of intersecting pedestrian flows based on experiments, Physica A: Statistical Mechanics and its Applications 405 (2014) 316-325. 
[102] S. P. Hoogendoorn, W. Daamen, Pedestrian Behavior at Bottlenecks, Transportation Science 39 (2005) $147-159$.

[103] J. Zhang, W. Klingsch, A. Schadschneider, A. Seyfried, Experimental Study of Pedestrian Flow Through a TJunction, in: V. V. Kozlov, A. P. Buslaev, A. S. Bugaev, M. V. Yashina, A. Schadschneider, M. Schreckenberg (Eds.), Traffic and Granular Flow '11, Springer Berlin Heidelberg, Berlin, Heidelberg, 2013, pp. $241-249$. doi $10.1007 / 978-3-642-39669-4\{\backslash$ textunderscore\}23

[104] J. Zhang, S. Cao, A. Seyfried, Properties of pedestrian movement at signalized crosswalk, in: W. Song, J. Ma, L. Fu (Eds.), Proceedings of the 8th International Conference on Pedestrian and Evacuation Dynamics, 2016, pp. 126-130.

[105] T. J. Shields, K. E. Boyce, G. W. H. Silcock, B. Dunne, The impact of a wheelchair bound Evacuee on the speed and flow of evacuees in a stairway during an uncontrolled unannaunced evacuation, Journal of applied fire science 7 (1997) 29-39.

[106] J. G. Sørensen, A. S. Dederichs, Evacuation characteristics of visually impaired people - a qualitative and quantitative study, Fire and Materials 39 (2013) 385-395.

[107] J. G. Sørensen, A. S. Dederichs, Evacuation characteristics of visually impaired people - a qualitative and quantitative study, Fire and Materials 39 (2015) 385-395.

[108] V. V. Kholshchevnikov, D. A. Samoshin, A. P. Parfyonenko, I. P. Belosokhov, Study of children evacuation from preschool education institutions, Fire and Materials 36 (2012) 349-366.

[109] V. V. Kholshevnikov, D. A. Samoshin, R. Istratov, The problems of elderly people safe evacuation from senior citizen health care buildings in case of fire, in: T. J. Shields (Ed.), Human behaviour in fire, Interscience Communications, London, 2012, pp. 587-593.

[110] A. R. Larusdottir, A. Dederichs, Evacuation dynamics of children: Walking speed, flows through doors in daycare centers, in: R. D. Peacock, E. D. Kuligowski, J. D. Averill (Eds.), Pedestrian and evacuation dynamics, Springer, New York, 2011 .

[111] A. Larusdottir, A. Dederichs, A Step Towards Including Children's Evacuation Parameters and Behavior in Fire Safe Building Design, Fire Safety Science 10 (2011) 187-195.

[112] A. R. Larusdottir, A. S. Dederichs, Evacuation of Children: Movement on Stairs and on Horizontal Plane, Fire Technology 48 (2012) 43-53.

[113] H. Kladek, Über die Geschwindigkeitscharakteristik auf Stadtstraßenabschnitten, Dissertation, Hochschule für Verkehrswesen „Friedrich List“, Dresden, 1966.

[114] H. Nelson, F. Mowrer, Emergency Movement, in: P. J. DiNenno (Ed.), SFPE handbook of fire protection engineering, NFPA, National Fire Protection Association, Quincy and Mass, 2002, pp. 3/367-3/380.

[115] J. G. Sørensen, A. Dederichs, Evacuation characteristics of blind and visually impaired people: Walking Speeds on horizontal planes and descending stairs, in: T. J. Shields (Ed.), Human behaviour in fire, Interscience Communications, London, 2012

[116] B. Steffen, A. Seyfried, Methods for measuring pedestrian density, flow, speed and direction with minimal scatter, Physica A: Statistical Mechanics and its Applications 389 (2010) 1902-1910.

[117] M. Boltes, J. Zhang, A. Tordeux, A. Schadschneider, A. Seyfried, Empirical Results of Pedestrian and Evacuation Dynamics, in: R. A. Meyers (Ed.), Encyclopedia of complexity and systems science, SpringerReference, 2018.

[118] J. D. Averill, D. S. Mileti, R. D. Peacock, E. D. Kuligowski, N. Groner, G. Proulx, P. A. Reneke, H. E. Nelson, Occupant Behavior, Egress, and Emergency Communication. Federal Building and Fire Safety Investigation of the World Trade Center Disaster. NIST NCSTAR 1-7, 2005.

[119] M. Spearpoint, H. A. MacLennan, The effect of an ageing and less fit population on the ability of people to egress buildings, Safety Science 50 (2012) 1675-1684.

[120] E. Steinfeld, Access to the Built Environment: A Review of Literature, volume 405 of Us Dept. of Housing and Urban Development Office of Policy Development and Research Hud-Pdr, 1980.

[121] J. Pauls, J. J. Fruin, J. M. Zupan, Minimum Stair Width for Evacuation, Overtaking Movement and Counterflow Technical Bases and Suggestions for the Past, Present and Future, in: N. Waldau, P. Gattermann, H. Knoflacher, M. Schreckenberg (Eds.), Pedestrian and Evacuation Dynamics 2005, Springer-Verlag Berlin Heidelberg, Berlin, Heidelberg, 2007, pp. 57-69.

[122] M. Hulens, G. Vansant, A. L. Claessens, R. Lysens, E. Muls, Predictors of 6-minute walk test results in lean, obese and morbidly obese women, Scandinavian Journal of Medicine and Science in Sports 13 (2003) 98-105.

[123] C. R. Gale, M. Allerhand, A. A. Sayer, C. Cooper, I. J. Deary, The dynamic relationship between cognitive function and walking speed: the English Longitudinal Study of Ageing, Age (Dordrecht, Netherlands) 36 (2014) 9682.

[124] C. S. Jiang, S. Z. Zheng, F. Yuan, H. J. Jia, Z. N. Zhan, J. J. Wang, Experimental assessment on the moving capabilities of mobility-impaired disabled, Safety Science 50 (2012) 974-985.

[125] L. Edie, Discussion of Traffic Stream Measurements and Definitions, in: A. Joyce (Ed.), Proceedings of the Second International Symposium on the Theory of Traffic Flow, 1963, pp. 139-154.

[126] M. S. Sharifi, K. Christensen, A. Chen, D. Stuart, Y. S. Kim, Y. Chen, A large-scale controlled experiment on pedestrian walking behavior involving individuals with disabilities, Travel Behaviour and Society 8 (2017) 14-25.

\section{Appendix I - engineering egress data}


Table 3: Pre-movement depending on mobility characteristics.

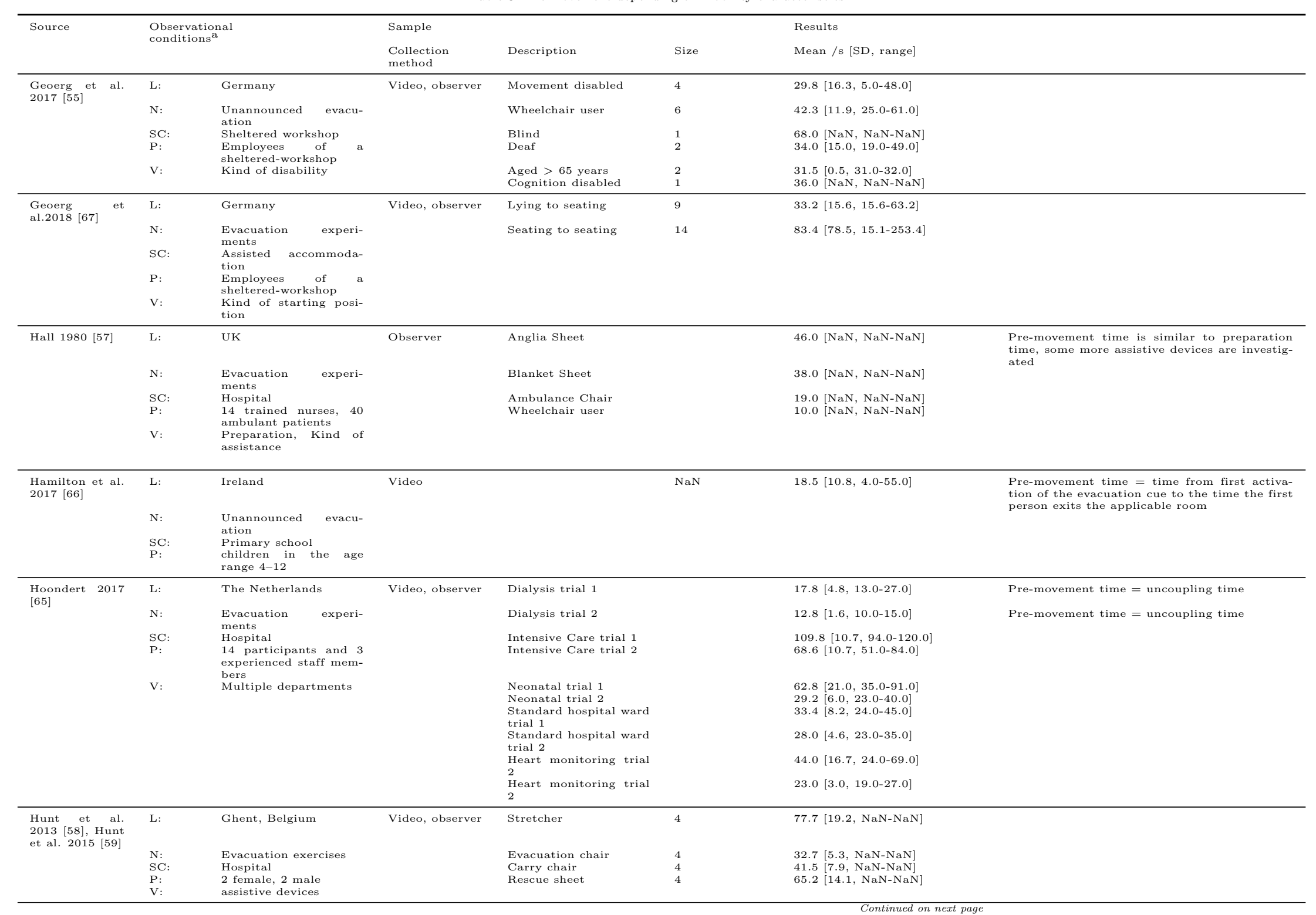


Table 3 - Continued from prevos pase

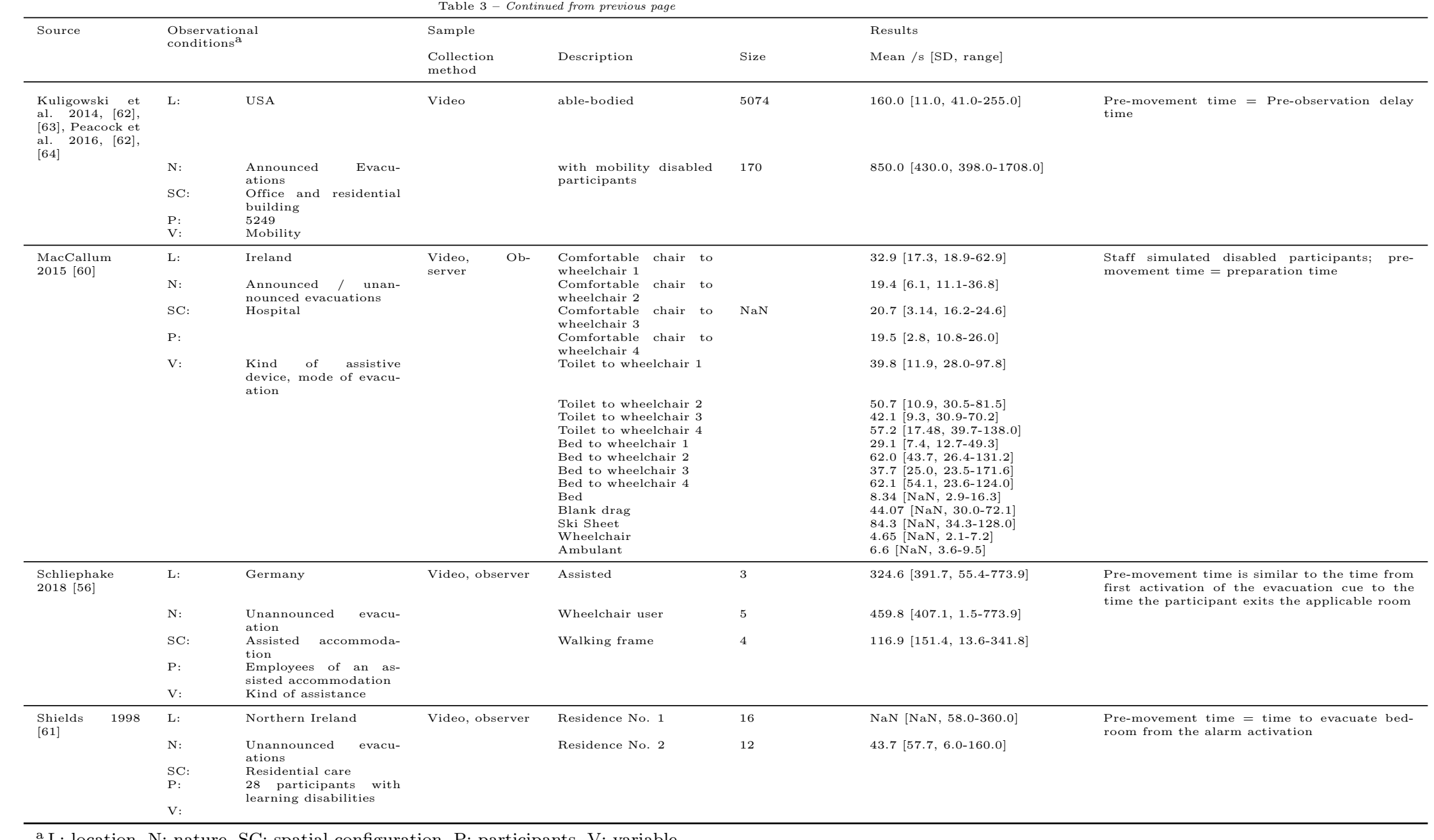

${ }^{a}$ L: location, N: nature, SC: spatial configuration, P: participants, V: variable. 
Table 4: Movement speed depending on mobility characteristics.

\begin{tabular}{|c|c|c|c|c|c|c|c|}
\hline Reference & \multicolumn{2}{|c|}{$\begin{array}{l}\text { Observational } \\
\text { conditions }^{\mathrm{a}}\end{array}$} & \multicolumn{3}{|l|}{ Sample } & \multicolumn{2}{|l|}{ Results } \\
\hline \multirow{10}{*}{$\begin{array}{l}\text { Cabrerea et al. } \\
2016[71 \|\end{array}$} & & & & & & & \\
\hline & $\mathrm{L}:$ & Peru & & $\begin{array}{l}\text { Walking alone (age 60- } \\
69 \text { ) }\end{array}$ & 120 & $1.15[0.18, \mathrm{NaN}-\mathrm{NaN}]$ & \\
\hline & $\mathrm{N}:$ & Field study & & $\begin{array}{l}\text { Walking alone (age } 70- \\
79 \text { ) }\end{array}$ & 120 & $1.08[0.20, \mathrm{NaN}-\mathrm{NaN}]$ & \\
\hline & SC: & Park & & $\begin{array}{l}\text { Walking alone (age } 80- \\
90 \text { ) }\end{array}$ & 120 & $0.87[0.17, \mathrm{NaN}-\mathrm{NaN}]$ & \\
\hline & P: & Pedestrians & & Walking with a stick & 40 & $1.06[0.17, \mathrm{NaN}-\mathrm{NaN}]$ & \\
\hline & $\mathrm{v}:$ & Elderly & & $\begin{array}{l}\text { (age 60-69) } \\
\text { Walking with a stick } \\
\text { (age 70-79) }\end{array}$ & 40 & $0.75[0.14, \mathrm{NaN}-\mathrm{NaN}]$ & \\
\hline & & & & $\begin{array}{l}\text { Walking with a stick } \\
\text { (age 80-90) }\end{array}$ & 40 & $0.63[0.12, \mathrm{NaN}-\mathrm{NaN}]$ & \\
\hline & & & & $\begin{array}{l}\text { Walking with a walker } \\
\text { (age } 60-69)\end{array}$ & 30 & $0.85[0.09, \mathrm{NaN}-\mathrm{NaN}]$ & \\
\hline & & & & $\begin{array}{l}\text { Walking with a walker } \\
\text { (age 70-79) }\end{array}$ & 30 & $0.59[0.06, \mathrm{NaN}-\mathrm{NaN}]$ & \\
\hline & & & & $\begin{array}{l}\text { Walking with a walker } \\
\text { (age 80-90) }\end{array}$ & 30 & $0.49[0.12, \mathrm{NaN}-\mathrm{NaN}]$ & \\
\hline \multirow{2}{*}{$\begin{array}{l}\text { Dai et al. } 2010 \\
82 \pi\end{array}$} & $\mathrm{L}:$ & China & Video & Female $(15-55)$ & $\mathrm{NaN}$ & $1.10[\mathrm{NaN}, 0.93-1.33]$ & Age of agents estimated by the authors \\
\hline & $\begin{array}{l}\text { N: } \\
\text { SC: } \\
\text { P: }\end{array}$ & $\begin{array}{l}\text { Field study } \\
\text { Shopping center } \\
\text { Visitors }\end{array}$ & & $\begin{array}{l}\text { Male }(15-55) \\
\text { Old man- } 55-70) \\
\text { Child }(6-14)\end{array}$ & $\begin{array}{l}\text { N/A } \\
\text { N/A } \\
\text { NaN }\end{array}$ & $\begin{array}{l}1.14 \text { [NaN, } 0.92-1.36] \\
0.98[\mathrm{NaN}, 0.86-1.10] \\
0.81[\mathrm{NaN}, 0.70-0.94]\end{array}$ & \\
\hline \multirow[t]{15}{*}{$\begin{array}{l}\text { Deshpande et } \\
\text { al. } 2009 \text { [72] }\end{array}$} & $\mathrm{L}:$ & Italy & & Overall, usual speed & & $1.23[0.26, \mathrm{NaN}-\mathrm{NaN}]$ & 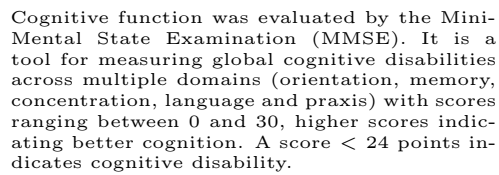 \\
\hline & $\mathrm{N}:$ & $\begin{array}{l}\text { Evacuation experi- } \\
\text { ments }\end{array}$ & & Overall, fast speed & & $1.49[0.33, \mathrm{NaN}-\mathrm{NaN}]$ & \\
\hline & SC: & & & $\begin{array}{l}\text { Overall, walking-while- } \\
\text { talking-speed }\end{array}$ & & $0.98[0.28, \mathrm{NaN}-\mathrm{NaN}]$ & \\
\hline & P: & $\begin{array}{l}660 \text { participants aged } \\
\text { over } 65\end{array}$ & & $\begin{array}{l}\text { MMSE } 28-30 \text { (Quart- } \\
\text { ile I), usual speed }\end{array}$ & & $1.36[0.22, \mathrm{NaN}-\mathrm{NaN}]$ & \\
\hline & $\mathrm{V}:$ & $\begin{array}{l}\text { Gait speed, cognitive } \\
\text { decline }\end{array}$ & & $\begin{array}{l}\text { MMSE } 28-30 \text { (Quart- } \\
\text { ile I), fast speed }\end{array}$ & & $1.66[0.29, \mathrm{NaN}-\mathrm{NaN}]$ & \\
\hline & & & & $\begin{array}{l}\text { MMSE 28-30 (Quart- } \\
\text { ile I) walking-while- } \\
\text { talking-speed }\end{array}$ & & $1.07[0.26, \mathrm{NaN}-\mathrm{NaN}]$ & \\
\hline & & & & $\begin{array}{l}\text { MMSE }=27 \text { (Quartile } \\
\text { II), usual speed }\end{array}$ & & $1.22[0.22, \mathrm{NaN}-\mathrm{NaN}]$ & \\
\hline & & & & $\begin{array}{l}\text { MMSE }=27 \text { (Quartile } \\
\text { II), fast speed }\end{array}$ & & $1.46[0.26, \mathrm{NaN}-\mathrm{NaN}]$ & \\
\hline & & & & $\begin{array}{l}\text { MMSE = } 27 \text { (Quart- } \\
\text { ile II), walking-while- } \\
\text { talking-speed }\end{array}$ & & $1.01[0.25, \mathrm{NaN}-\mathrm{NaN}]$ & \\
\hline & & & & $\begin{array}{l}\text { MMSE } \\
\begin{array}{l}\text { Muartile } \\
\text { speed }\end{array}\end{array}=\begin{array}{rl}24 & 26 \\
\text { III), } & \text { usual }\end{array}$ & & $1.22[0.24]$, & \\
\hline & & & & $\begin{array}{l}\text { MMMSE } \\
\text { (Quartile }\end{array}=\begin{array}{r}24 \\
\text { III) }),\end{array} \quad \begin{array}{r}26 \\
\text { fast }\end{array}$ & & $1.48[0.33, \mathrm{NaN}-\mathrm{NaN}]$ & \\
\hline & & & & $\begin{array}{l}\text { MMSE = }=24-26 \\
\text { (Quartile III), walking- } \\
\text { while-talking-speed }\end{array}$ & & $0.99[0.29, \mathrm{NaN}-\mathrm{NaN}]$ & \\
\hline & & & & $\begin{array}{l}\text { Whine-talningspeed }<24 \text { (Quartile } \\
\text { MVSE } \\
\text { IV), usual speed }\end{array}$ & & $1.13[0.28, \mathrm{NaN}-\mathrm{NaN}]$ & \\
\hline & & & & MMSE $<24$ (Quartile & & $1.35[0.34, \mathrm{NaN}-\mathrm{NaN}]$ & \\
\hline & & & & $\begin{array}{l}\text { MMSE }<24 \text { (Quart- } \\
\text { ile IV), walking-while- } \\
\text { talking-speed }\end{array}$ & & $0.90[0.27, \mathrm{NaN}-\mathrm{NaN}]$ & \\
\hline $\begin{array}{l}\text { Fitzpatrick } \\
\text { al. } 2007[73]\end{array}$ & $\mathrm{L}:$ & USA & & Age $75-79$, usual gait & 2014 & $0.97[0.22, \mathrm{NaN}-\mathrm{NaN}]$ & $\begin{array}{l}\text { Movement = gait speed; results from 15-foot- } \\
\text { walk }\end{array}$ \\
\hline
\end{tabular}


Table 4 - Contimed from previous puse

\begin{tabular}{|c|c|c|c|c|c|c|c|}
\hline Reference & \multicolumn{2}{|c|}{$\begin{array}{l}\text { Observational } \\
\text { conditions }^{a}\end{array}$} & \multicolumn{3}{|l|}{ Sample } & \multicolumn{2}{|l|}{ Results } \\
\hline & $\mathrm{N}:$ & $\begin{array}{l}\text { Evacuation experi- } \\
\text { ments }\end{array}$ & & Age $75-79$, fast gait & 2014 & $1.39[0.65, \mathrm{NaN}-\mathrm{NaN}]$ & \\
\hline & $\begin{array}{l}\text { SC: } \\
\text { P: }\end{array}$ & 370 & & $\begin{array}{l}\text { Age } 80-84 \text {, usual gait } \\
\text { Age } 80-84 \text {, fast gait }\end{array}$ & $\begin{array}{l}838 \\
838\end{array}$ & $\begin{array}{l}0.92[0.26, \mathrm{NaN}-\mathrm{NaN}] \\
1.30[0.41, \mathrm{NaN}-\mathrm{NaN}]\end{array}$ & \\
\hline & & $\begin{array}{l}\text { Age, gender, race, edu- } \\
\text { cation, BMI, several } \\
\text { clinical aspects }\end{array}$ & & Age $85+$, usual gait & 183 & $0.83[0.22, \mathrm{NaN}-\mathrm{NaN}]$ & \\
\hline & & & & Age $85+$, fast gait & 183 & $1.16[0.32, \mathrm{NaN}-\mathrm{NaN}]$ & \\
\hline & & & & $\begin{array}{l}\text { Male, usual gait } \\
\text { Male, fast gait }\end{array}$ & $\begin{array}{l}1399 \\
1399\end{array}$ & $1.41[0.62$, NaN-NaN] & \\
\hline & & & & $\begin{array}{l}\text { Female, usual gait } \\
\text { Female, fast gait }\end{array}$ & $\begin{array}{l}1636 \\
1636\end{array}$ & 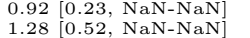 & \\
\hline & & & & $\begin{array}{l}\text { BMI }<20.0 \text {, usual gait } \\
\text { BMI }<20.0 \text {, fast gait }\end{array}$ & $\begin{array}{l}79 \\
79\end{array}$ & $\begin{array}{l}1.0[0.26 \text {, NaN-NaN] } \\
1.46[0.78 \text {, NaN-NaN] }\end{array}$ & \\
\hline & & & & BMI $20.1-25.0$, usual & 900 & $0.98[0.24$, NaN-NaN $]$ & \\
\hline & & & & BMI $20.1-25.0$, fast & 900 & $1.38[0.35, \mathrm{NaN}-\mathrm{NaN}]$ & \\
\hline & & & & $\begin{array}{l}\text { BMI } 25.1-30.0 \text {, usual } \\
\text { gait }\end{array}$ & 1393 & $0.96[0.23, \mathrm{NaN}-\mathrm{NaN}]$ & \\
\hline & & & & BMI $25.1-30.0$, fast & 1393 & $1.36[0.49$, no $-\mathrm{no}]$ & \\
\hline & & & & $\begin{array}{l}\text { BMI > 30.0, usual gait } \\
\text { BMI > 30.0, fast gait } \\
\text { None mobility diffi- } \\
\text { culty, usual gait }\end{array}$ & $\begin{array}{l}654 \\
654 \\
2083\end{array}$ & $\begin{array}{l}0.7[0.20, \mathrm{NaN}-\mathrm{NaN}] \\
1.26[0.90, \mathrm{NaNNNaN}] \\
0.99[0.23, \mathrm{NaN-NaN}]\end{array}$ & \\
\hline & & & & $\begin{array}{l}\text { None mobility diffi- } \\
\text { culty, fast gait }\end{array}$ & 2083 & $1.42[0.66, \mathrm{NaN}-\mathrm{NaN}]$ & \\
\hline & & & & $\begin{array}{l}\text { One or more mobility } \\
\text { difficulties, usual gait }\end{array}$ & 951 & $0.86[0.22, \mathrm{NaN}-\mathrm{NaN}]$ & \\
\hline & & & & $\begin{array}{l}\text { One or more mobility } \\
\text { difficulties, fast gait }\end{array}$ & 951 & $1.19[0.31, \mathrm{NaN}-\mathrm{NaN}]$ & \\
\hline \multirow{5}{*}{$\begin{array}{l}\text { Fritz } \\
2013[79]\end{array}$} & L: & & \multirow[t]{5}{*}{$\begin{array}{l}\text { Motion analysis } \\
\text { system }\end{array}$} & \multirow{5}{*}{$\begin{array}{l}\text { Young }(24.1 \pm 2.5(21- \\
31)) \\
\text { Middle-aged } \\
7.9(35-61)) \\
\text { Elderly }(85.3 \pm 6.3 \pm(66- \\
98))\end{array}$} & 10 & $1.49[0.18,1.08-1.86]$ & \multirow{5}{*}{$\begin{array}{l}\text { Only male participants; focus of the study is } \\
\text { backward moving }\end{array}$} \\
\hline & $\mathrm{N}:$ & $\begin{array}{l}\text { Evacuation experi- } \\
\text { ments }\end{array}$ & & & 4 & $1.48[0.22,1.10-1.90]$ & \\
\hline & SC: & Electronic walkway & & & 12 & $1.07[0.31,0.43-2.01]$ & \\
\hline & P: & $\begin{array}{l}\text { young, middle-aged and } \\
\text { elderly }\end{array}$ & & & & & \\
\hline & $\mathrm{v}:$ & & & & & & \\
\hline \multirow{3}{*}{$\begin{array}{l}\text { Gates et al. } \\
1986[74 \|\end{array}$} & L: & USA & & $<30$ years & 894 & $1.48[0.20, \mathrm{NaN}-\mathrm{NaN}]$ & \multirow[t]{3}{*}{$\begin{array}{l}\text { Age and type of disabilities estimated by video } \\
\text { observer }\end{array}$} \\
\hline & $\begin{array}{l}\text { N: } \\
\text { SC: } \\
\text { P: }\end{array}$ & $\begin{array}{l}\text { Field study } \\
\text { Crossing at intersection } \\
\text { Pedestrians }\end{array}$ & & $\begin{array}{l}30-64 \\
>65 \\
\text { Disabled }\end{array}$ & $\begin{array}{l}662 \\
326 \\
10\end{array}$ & $\begin{array}{l}1.44[0.21, \mathrm{NaN}-\mathrm{NaN}] \\
1.16[0.26, \mathrm{NaN}-\mathrm{NaN}] \\
1.18[0.24, \mathrm{NaN}-\mathrm{NaN}]\end{array}$ & \\
\hline & & $\begin{array}{l}\text { Age, group size, disab- } \\
\text { ility }\end{array}$ & & Child with adult & & $1.22[0.18, \mathrm{NaN}-\mathrm{NaN}]$ & \\
\hline \multirow{4}{*}{$\begin{array}{l}\text { Geoerg et al. } \\
2018[67 \|\end{array}$} & L: & Germany & \multirow[t]{4}{*}{ Video, observer } & Wheelchair & 24 & $2.4[0.37,1.61-2.92]$ & \\
\hline & $\begin{array}{l}\mathrm{N}: \\
\mathrm{SC}:\end{array}$ & $\begin{array}{l}\text { Laboratory conditions } \\
\text { Assisted accommoda- }\end{array}$ & & $\begin{array}{l}\text { Evacuation chair } \\
\text { Escape mattress }\end{array}$ & $\begin{array}{l}8 \\
2\end{array}$ & $\begin{array}{l}2.13[0.66,0.85-2.98] \\
1.06[\mathrm{NaN}, 0.97-1.15]\end{array}$ & \\
\hline & P: & $\begin{array}{l}\text { tion } \\
\text { Employees of a }\end{array}$ & & & & & \\
\hline & $\mathrm{v}:$ & $\begin{array}{l}\text { sheltered-workshop } \\
\text { Kind of starting posi- } \\
\text { tion }\end{array}$ & & & & & \\
\hline \multirow[t]{2}{*}{ Hall 1980 [57] } & $\begin{array}{l}\text { L: } \\
\text { N: }\end{array}$ & $\begin{array}{l}\text { UK } \\
\text { Evacuation }\end{array}$ & \multirow[t]{2}{*}{ Observer } & \multicolumn{2}{|l|}{$\begin{array}{l}\text { Anglia sheet } \\
\text { Mercury straps }\end{array}$} & \multicolumn{2}{|l|}{$\begin{array}{l}0.43[\mathrm{NaN}, \mathrm{NaN}-\mathrm{NaN}] \\
0.32[\mathrm{NaN}, \mathrm{NaN}-\mathrm{NaN}]\end{array}$} \\
\hline & $\begin{array}{l}\text { SC: } \\
\text { P: } \\
\text { V: }\end{array}$ & $\begin{array}{l}\text { Hospital } \\
14 \text { nurses, } \\
\text { Preparation, assistance }\end{array}$ & & \multicolumn{2}{|l|}{$\begin{array}{l}\text { Mattress lines } \\
\text { Blanket } \\
\text { Bed } \\
\text { Two-handed lift } \\
\text { Three-handed lift } \\
\text { Four-handed lift }\end{array}$} & $\begin{array}{l}0.20[\mathrm{NaN}, \mathrm{NaN}-\mathrm{NaN}] \\
0.40[\mathrm{NaN}, \mathrm{NaN-NaN}] \\
0.91[\mathrm{NaN}, \mathrm{NaN}-\mathrm{NaN}] \\
1.11[\mathrm{NaN}, \mathrm{NaN}-\mathrm{NaN}] \\
0.77 \text { [NaN, NaN-NaN] } \\
1.00[\mathrm{NaN}, \mathrm{NaN-NaN}] \\
\text { Continued on }\end{array}$ & \\
\hline
\end{tabular}


Table 4 - Continued from prevus page

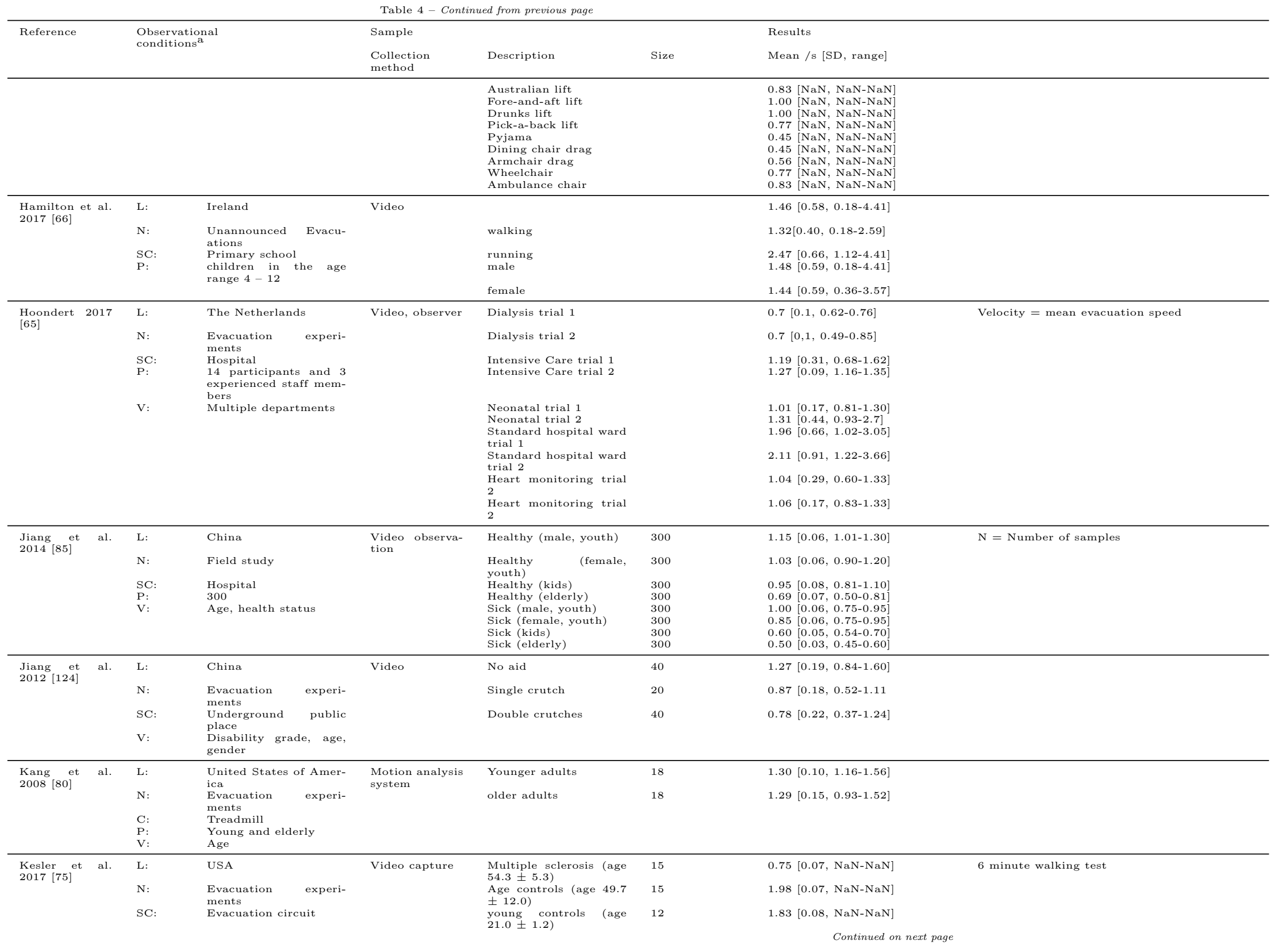


Table 4 - Continued from pregress

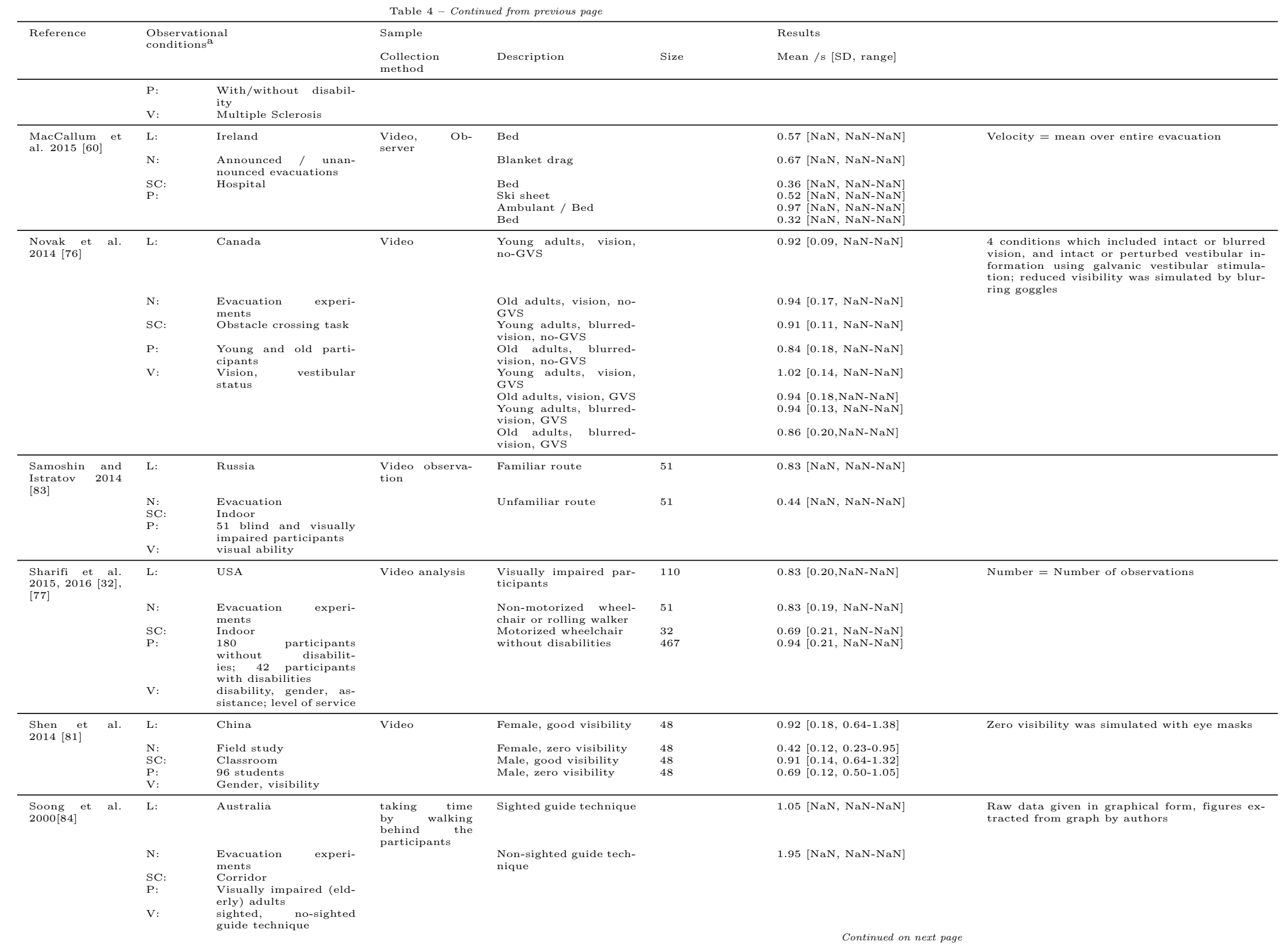


Table 4 - Continued from previous page

\begin{tabular}{|c|c|c|c|c|c|c|c|}
\hline Reference & \multicolumn{2}{|c|}{$\begin{array}{l}\text { Observational } \\
\text { conditions }^{\mathrm{a}}\end{array}$} & \multicolumn{3}{|l|}{ Sample } & \multicolumn{2}{|l|}{$\begin{array}{l}\text { Results } \\
\text { Mean /s [SD, range] }\end{array}$} \\
\hline \multirow{4}{*}{$\begin{array}{l}\text { Tsuchiya et al. } \\
2007[78 \|\end{array}$} & & & \multirow{4}{*}{ Stopwatch } & \multirow{2}{*}{\multicolumn{2}{|c|}{ Non disabled, men }} & & \multirow{4}{*}{$\begin{array}{l}\text { Wheelchairs were used by participants without } \\
\text { disabilities }\end{array}$} \\
\hline & L: & Japan & & & & $1.33[0.17, \mathrm{NaN}-\mathrm{NaN}]$ & \\
\hline & $\begin{array}{l}\text { N: } \\
\text { SC: } \\
\text { P: }\end{array}$ & $\begin{array}{l}\text { Laboratory Experiment } \\
\text { Walkway in a campus } \\
\text { College students, } 202 \\
\text { male, } 75 \text { female }\end{array}$ & & \multirow{2}{*}{\multicolumn{2}{|c|}{$\begin{array}{l}\text { Non disabled, woman } \\
\text { Wheelchair users, men } \\
\text { Wheelchair users, wo- } \\
\text { man }\end{array}$}} & 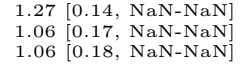 & \\
\hline & $\mathrm{V}:$ & & & & & & \\
\hline
\end{tabular}


Table 5: Fundamental diagrams considering pedestrians with disabilities.

\begin{tabular}{|c|c|c|c|c|c|c|c|}
\hline \multirow[t]{2}{*}{ Reference } & \multicolumn{2}{|c|}{$\begin{array}{l}\text { Observational } \\
\text { conditions }^{\mathrm{a}}\end{array}$} & \multicolumn{2}{|l|}{ Sample } & \multicolumn{3}{|l|}{ Quantities } \\
\hline & & & Measurement method & $\begin{array}{l}\text { Data } \\
\text { points }\end{array}$ & $\rho / \mathrm{m}^{-2}$ & $v / \mathrm{ms}^{-1}$ & $J / \mathrm{s}^{-1}$ \\
\hline \multirow{2}{*}{$\begin{array}{l}\text { Guo et al. } 2016 \\
981\end{array}$} & $\mathrm{~L}:$ & China & \multirow{2}{*}{$\begin{array}{l}\text { Method B as defined in } \\
1001\end{array}$} & \multirow[t]{2}{*}{74} & \multirow[t]{2}{*}{$0.85(0.42,0.06-1.62)$} & \multirow[t]{2}{*}{$1.20(1.01,0.54-6.89)$} & \multirow[t]{2}{*}{$0.74(0.17,0.37-1.32)$} \\
\hline & $\begin{array}{l}\text { N: } \\
\text { SC: } \\
\text { P: } \\
\text { V: } \\
\text { T: }\end{array}$ & $\begin{array}{l}\text { Laboratory Experiment } \\
\text { ring-shaped corridor } \\
\text { Students } \\
\text { Number, Visibility } \\
\text { Unidirectional, bidirec- } \\
\text { tional }\end{array}$ & & & & & \\
\hline \multirow{2}{*}{$\begin{array}{l}\text { Kholshevnikov } \\
\text { et al. } \\
109] \\
\end{array}$} & L: & Russia & \multirow[t]{2}{*}{$\begin{array}{l}\text { Method } \mathrm{A} \text { as defined in } \\
100 \|\end{array}$} & \multirow[t]{2}{*}{-} & \multirow{2}{*}{\multicolumn{3}{|c|}{ Quantities were plotted by using Eq 1 with $v_{0}=0.43 \mathrm{~m} \mathrm{~s}^{-1}, \alpha=0.43$ and $\rho_{\max }=1.028 \mathrm{~m}^{-2}$}} \\
\hline & $\begin{array}{l}\text { N: } \\
\text { SC: } \\
\text { P: } \\
\text { V: } \\
\text { T: }\end{array}$ & $\begin{array}{l}\text { Evacuation training } \\
\text { Corridor } \\
\text { Elderly } \\
\text { Type of assistance }\end{array}$ & & & & & \\
\hline \multirow{2}{*}{$\begin{array}{l}\text { Samoshin et al. } \\
2014[83 \|\end{array}$} & L: & Russia & \multirow{2}{*}{$\begin{array}{l}\text { Method } \mathrm{A} \text { as defined in } \\
1001\end{array}$} & \multirow[t]{2}{*}{-} & \multirow{2}{*}{\multicolumn{3}{|c|}{ Quantities were plotted by using Eq 1 with $v_{0}=0.83 \mathrm{~m} \mathrm{~s}^{-1}, \alpha=0.4919$ and $\rho_{\max }=1.03 \mathrm{~m}^{-2}$}} \\
\hline & $\begin{array}{l}\text { N: } \\
\text { SC: } \\
\text { P: } \\
\text { V: } \\
\text { T: }\end{array}$ & $\begin{array}{l}\text { Evacuation training } \\
\text { Corridor } \\
\text { Visual impaired volun- } \\
\text { teers } \\
\text { Loss of vision } \\
\text { unidirectional }\end{array}$ & & & & & \\
\hline \multirow{2}{*}{$\begin{array}{l}\text { Sharifi et al. } \\
2015] 32], \\
126]\end{array}$} & L: & USA & \multirow{2}{*}{$\begin{array}{l}\text { Generalisation of Edie- } \\
\text { method } 125 \rrbracket\end{array}$} & \multirow[t]{2}{*}{-} & \multirow{2}{*}{\multicolumn{3}{|c|}{ Quantities were plotted by using Eq 1 with $v_{0}=1.01 \mathrm{~m} \mathrm{~s}^{-1}, \alpha=0.913$ and $\rho_{\max }=5.4 \mathrm{~m}^{-2}$}} \\
\hline & $\begin{array}{l}\text { N: } \\
\text { SC: } \\
\text { P: } \\
\text { V: } \\
\text { T: }\end{array}$ & $\begin{array}{l}\text { Laboratory Experiment } \\
\text { Circuit } \\
\text { Students } \\
\text { Type of disability, type } \\
\text { of facility } \\
\text { Unidirectional }\end{array}$ & & & & & \\
\hline \multirow{2}{*}{ 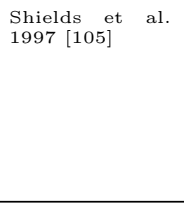 } & $\mathrm{L}:$ & Northern Ireland & \multirow{2}{*}{$\begin{array}{l}\text { Method } \mathrm{A} \text { as defined in } \\
100 \|\end{array}$} & \multirow[t]{2}{*}{8} & \multirow[t]{2}{*}{$1.84(0.57,0.49-2.56)$} & \multirow[t]{2}{*}{$0.66(0.38,0.30-1.49)$} & \multirow[t]{2}{*}{$3.71(2.20,1.29-6.53)$} \\
\hline & $\begin{array}{l}\text { N: } \\
\text { SC: } \\
\text { P: } \\
\text { V: } \\
\text { T: }\end{array}$ & $\begin{array}{l}\text { Unannounced evacu- } \\
\text { ation } \\
\text { Building } \\
\text { Students } \\
\text { Wheelchair usage, per- } \\
\text { sonal assistance } \\
\text { Stairway }\end{array}$ & & & & & \\
\hline \multirow{3}{*}{$\begin{array}{l}\text { Soerensen } \\
\text { et al. } \\
\text { 2015 } 2013,106], \text { 107 }\end{array}$} & L: & Denmark & \multirow[t]{3}{*}{$\begin{array}{l}\text { Method } \mathrm{A} \text { as defined in } \\
100\end{array}$} & \multirow[t]{3}{*}{210} & \multirow[t]{3}{*}{$0.92(0.40,0.49-2.24)$} & \multirow[t]{3}{*}{$0.83(0.36,0.27-1.92)$} & \multirow[t]{3}{*}{$0.72(0.37,0.17-1.92)$} \\
\hline & $\begin{array}{l}\text { N: } \\
\text { SC: } \\
\text { P: }\end{array}$ & $\begin{array}{l}\text { Laboratory Experiment } \\
\text { Corridor } \\
\text { Students, naturally }\end{array}$ & & & & & \\
\hline & $\begin{array}{l}\text { V: } \\
\text { T: }\end{array}$ & $\begin{array}{l}\text { blind participants } \\
\text { Loss of vision } \\
\text { unidirectional }\end{array}$ & & & & & \\
\hline \multirow{2}{*}{$\begin{array}{l}\text { Tsuchiya et al. } \\
2007[78 \|\end{array}$} & $\mathrm{L}:$ & Japan & \multirow{2}{*}{$\begin{array}{l}\text { Method } \mathrm{A} \text { as defined in } \\
100 \|\end{array}$} & 34 & $1.36(0.20,1.02-1.79)$ & $1.51(0.14,1.32-1.82)$ & $2.06(0.45,1.34-3.13)$ \\
\hline & $\begin{array}{l}\text { N: } \\
\text { SC: } \\
\text { P: } \\
\text { V: } \\
\text { T: }\end{array}$ & $\begin{array}{l}\text { Laboratory Experiment } \\
\text { Corridor (walkway) } \\
\text { Students } \\
\text { Wheelchair } \\
\text { width } \\
\text { Unidirectional }\end{array}$ & & & & & \\
\hline $\begin{array}{l}{ }^{a} \text { L: location, } \\
\text { b Method A: } 1 \\
\text { c Method B: N }\end{array}$ & & $\begin{array}{l}\text { SC: spatial config } \\
\text { mean values of flo } \\
\text { mean values of vel }\end{array}$ & tion, P: participant & $V: v$ & $\begin{array}{l}\text { iable. } \\
x \text { and tin }(\Delta t) \text { at }\end{array}$ & $(x)$. & \\
\hline
\end{tabular}




\section{Appendix II - Keyword and truncations}

Table 6: Keywords and truncations used to find publications dealing with engineering egress data considering pedestrians with disabilities or reduced performance.

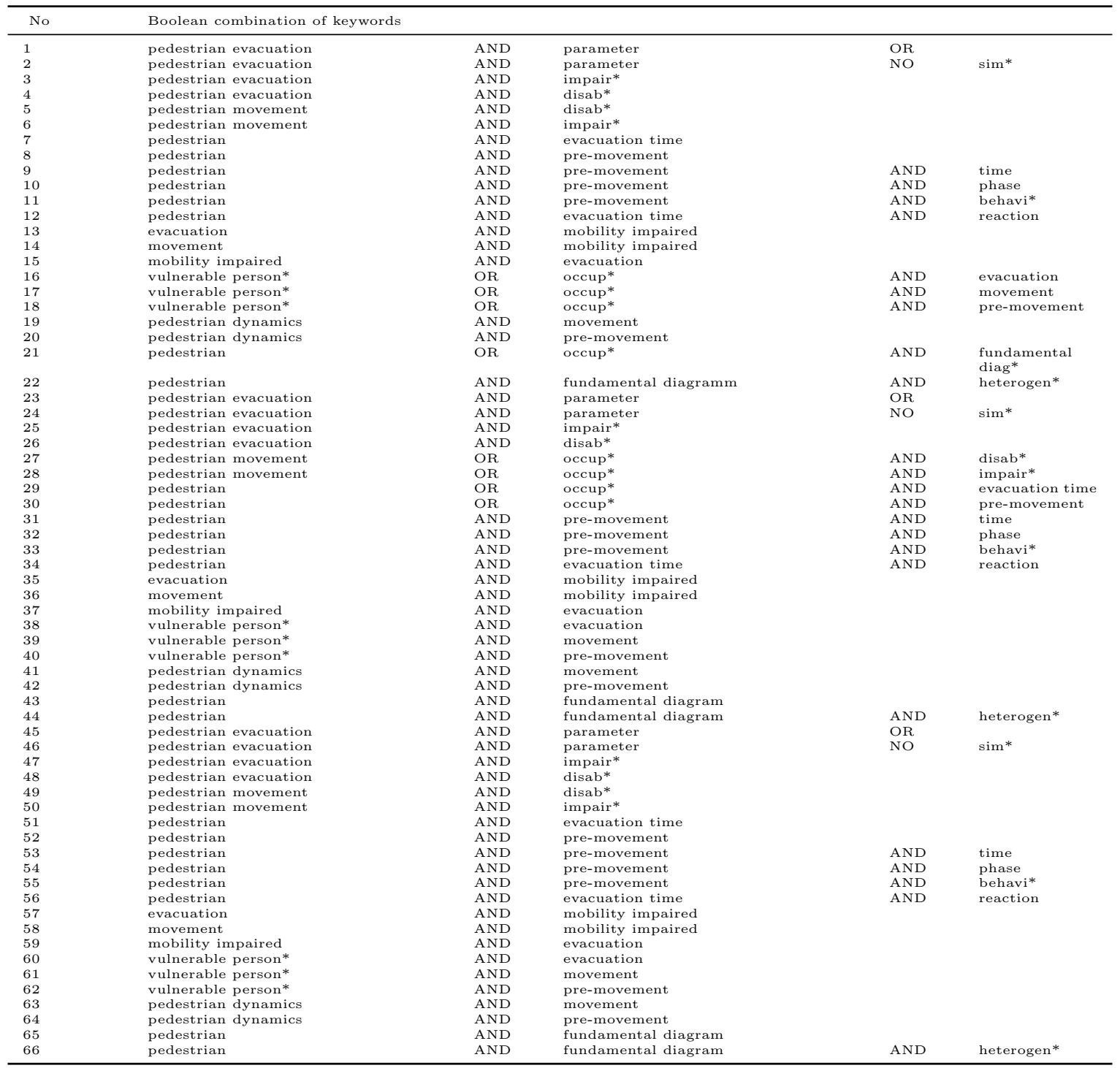

